\title{
Convective and wave signatures in ozone profiles over the equatorial Americas: Views from TC4 (2007) and SHADOZ
}

Anne M. Thompson ${ }^{1}$, Alaina M. MacFarlane ${ }^{1,2}$, Gary A. Morris ${ }^{3}$, John E. Yorks ${ }^{1,4}$, Sonya K. Miller $^{1}$, Brett F. Taubman ${ }^{5}$, Gé Verver ${ }^{6}$, Holger Vömel ${ }^{7}$, Melody A. Avery ${ }^{8}$, Johnathan W. Hair ${ }^{8}$, Glenn S. Diskin ${ }^{8}$, Edward V. Browell ${ }^{8}$, Jéssica Valverde Canossa ${ }^{8}$, Tom L. Kucsera ${ }^{10}$,

Christopher A. Klich ${ }^{1}$, Dennis L. Hlavka ${ }^{4}$

${ }^{1}$ The Pennsylvania State University, Department of Meteorology

${ }^{2}$ Now at National Weather Service Middle Atlantic River Forecast Center

${ }^{3}$ Valparaiso University, Dept of Physics and Astronomy

${ }^{4}$ SSAI; also at NASA/Goddard Space Flight Center

${ }^{5}$ Appalachian State University, Dept of Chemistry

${ }^{6}$ KNMI (Royal Dutch Meteorological Institute)

${ }^{7}$ DWD- Deutscher Wetterdienst, GRUAN - Lindenborg

${ }^{8}$ NASA/Langley Research Center

${ }^{9}$ Laboratorio de Análisis Ambiental, Escuela de Ciencias Ambientales, Universidad Nacional

${ }^{10}$ Univ Maryland Baltimore County - GEST; also at NASA/Goddard

\section{Popular Summary}

During the months of July-August 2007 NASA conducted a research campaign called the Tropical Composition, Clouds and Climate Coupling (TC4) experiment. Vertical profiles of ozone were measured daily using an instrument known as an ozonesonde, which is attached to a weather balloon and launch to altitudes in excess of $30 \mathrm{~km}$. These ozone profiles were measured over coastal Las Tablas, Panamá $(7.8 \mathrm{~N}, 80 \mathrm{~W})$ and several times per week at Alajuela, Costa Rica $(10 \mathrm{~N}, 84 \mathrm{~W})$. Meteorological systems in the form of waves, detected most prominently in 100$300 \mathrm{~m}$ thick ozone layer in the tropical tropopause layer, occurred in 50\% (Las Tablas) and 40\% (Alajuela) of the soundings. These layers, associated with vertical displacements and classified as gravity waves ("GW," possibly Kelvin waves), occur with similar structure and frequency over the Paramaribo (5.8N, 55W) and San Cristóbal (0.92S, 90W) sites of the Southern Hemisphere Additional Ozonesondes (SHADOZ) network. The gravity wave labeled layers in individual soundings correspond to cloud outflow as indicated by the tracers measured from the NASA DC-8 and other aircraft data, confirming convective initiation of equatorial waves. Layers representing quasi-horizontal displacements, referred to as Rossby waves, are robust features in soundings from 23 July to 5 August. The features associated with Rossby waves correspond to extra-tropical influence, possibly stratospheric, and sometimes to pollution transport. Comparison of Las Tablas and Alajuela ozone budgets with 1999-2007 Paramaribo and San Cristóbal soundings shows that TC4 is typical of climatology for the equatorial Americas. Overall during TC4, convection and associated meteorological waves appear to dominate ozone transport in the tropical tropopause layer.

Submitted to the TC4 Issue of JGR-Atmospheres (2009JD012909RR) 
19 May 2010 2009JD012909RR Submitted to the TC4 Issue of JGR-Atmospheres

\title{
Convective and wave signatures in ozone profiles over the equatorial Americas: Views from TC4 (2007) and SHADOZ
}

Anne M. Thompson, ${ }^{1}$ Alaina M. MacFarlane, ${ }^{1,2}$ Gary A. Morris,${ }^{3}$ John E. Yorks, ${ }^{1,4}$ Sonya K. Miller, ${ }^{1}$ Brett F. Taubman, ${ }^{5}$ Gé Verver ${ }^{6}{ }^{\text {Holger Vömel, }}{ }^{7}$ Melody A. Avery, ${ }^{8}$ Johnathan W. Hair, ${ }^{8}$ Glenn S. Diskin, ${ }^{8}$ Edward V. Browell, ${ }^{8}$ Jéssica Valverde Canossa, ${ }^{9}$ Tom L. Kucsera, ${ }^{10}$ Christopher A. Klich, ${ }^{1}$ Dennis L. Hlavka ${ }^{4}$

1 The Pennsylvania State University, Department of Meteorology, 503 Walker Building, University Park, PA 16802-5013 USA; anne@met.psu.edu; smiller@psu.edu; cok5018@psu.edu

${ }^{2}$ Now at National Weather Service Middle Atlantic River Forecast Center, State College, PA 16803; alaina.macfarlane@noaa.gov

3 Valparaiso University, Dept of Physics and Astronomy, Valparaiso, IN 46383 USA; gary.morris@valpo.edu

4 SSAI of Lanham, MD 20706 USA; also at NASA/Goddard Space Flight Center, Greenbelt, MD 20771 USA; john.e.yorks@nasa.gov; dennis.l.hlavka@nasa.gov

5 Appalachian State University, Dept of Chemistry, Boone, NC 28608; 828-262-7847; taubmanbf@appstate.edu

6 KNMI (Royal Dutch Meteorological Institute), de Bilt, NL; ge.verver@knmi.nl

7 DWD- Deutscher Wetterdienst, GRUAN - Lindenborg, Germany; Holger.voemel@dwd.de

8 NASA/Langley Research Center, MS 401B, Hampton, VA 23681; melody.a.avery@nasa.gov; glenn.s.diskin@nasa.gov; johnathan.w.hair@nasa.gov; edward.v.browell@nasa.gov

9 Laboratorio de Análisis Ambiental, Escuela de Ciencias Ambientales, Universidad Nacional P.O.Box: 86-300o Heredia, Costa Rica; 00506-88694960; jvalverde25@gmail.com

10 Univ Maryland Baltimore County - GEST, Baltimore, MD 21228; also at NASA/Goddard Space Flight Center, 301-614-6046; Tom.l.kucsera@nasa.gov

Keywords: Upper Troposphere/Lower Stratosphere; Ozonesondes; Tropical tropopause Layer; Gravity waves; Stratosphere-troposphere exchange

\author{
Running Head - Thompson et. al.: TC4, SHADOZ $\mathrm{O}_{3}$ \& Waves \\ Thompson et. al.: TC4, $\mathrm{SHADOZ} \mathrm{O}_{3} \&$ Waves
}


Convective and wave signatures in ozone profiles over the equatorial Americas: Views from $\mathrm{TC}_{4}(2007)$ and $\mathrm{SHADOZ}$

Abstract. During the $\mathrm{TC}_{4}$ (Tropical Composition, Clouds and Climate Coupling) campaign in July-August 2007, daily ozonesondes were launched over coastal Las Tablas, Panamá (7.8N, 8oW) and several times per week at Alajuela, Costa Rica (10N, 84W). Wave activity, detected most prominently in $100-300 \mathrm{~m}$ thick ozone laminae in the tropical tropopause layer, occurred in 50\% (Las Tablas) and 40\% (Alajuela) of the soundings. These layers, associated with vertical displacements and classified as gravity waves ("GW," possibly Kelvin waves) by laminar identification, occur with similar structure and frequency over the Paramaribo (5.8N, 55W) and San Cristóbal (o.92S, 9oW) individual soundings correspond to cloud outflow as indicated by DC- 8 tracers and other aircraft data, confirming convective initiation of equatorial waves. Layers representing quasi-horizontal displacements, referred to as Rossby waves by the laminar technique, are robust features in soundings from 23 July to 5 August. The features associated with Rossby waves correspond to extra-tropical influence, possibly stratospheric, and sometimes to pollution transport. Comparison of Las Tablas and Alajuela ozone budgets with 1999-2007 Paramaribo and San Cristóbal soundings shows that TC4 is typical of climatology for the equatorial Americas. Overall during $\mathrm{TC}_{4}$, convection and associated waves appear to dominate ozone transport in the tropical tropopause layer; intrusions from the extra-tropics occur throughout the free troposphere. 


\section{Introduction}

Ozone in the tropical troposphere reflects an interaction of photochemical and dynamical factors. The marine atmosphere is usually unpolluted, largely because the boundary layer (BL; see Appendix for abbreviations) is a region of $\mathrm{O}_{3}$ photochemical loss [Piotrowicz et al., 1991]. This is a consequence of slow formation (low $\mathrm{NO}_{\mathrm{x}}$ conditions;

destruction by halogens [Read et al., 2008]. In the free troposphere mixed sources converge [Thompson et al., 1996]. Advected pollution, stratospherically influenced air, and lightning add to $\mathrm{O}_{3}$ formation, the latter at rates according to time since a lightning episode (Thompson et al, 1997; see Cooper et al. [2006] and Bertram et al. [2007] for analyses of lightning influence in mid-latitudes). Extra-tropical ozone may also enrich ozone in the tropics [Randel et al., 2007].

Examination of ozone profiles from sondes or aircraft over remote tropical sites reveals the free troposphere as a region of low $\mathrm{O}_{3}(<30$ ppbv; Thompson et al., 2003a) alternating with layers of elevated $\mathrm{O}_{3}$ (sometimes $>100$ ppbv; Newell et al., 1999). From soundings taken through SHADOZ (Southern Hemisphere Additional Ozonesondes; Thompson et al., 2003a,b; 2010; submitted article available as Supplemental Material), SOWER [Stratospheric Ozone and Water in Equatorial Regions; Hasebe et al., 2007; Takashima and Shiotani, 2007] and related campaigns, much is known about the structure of $\mathrm{O}_{3}$ in the tropical upper troposphere (UT) and lower stratosphere (LS). Stable pollution layers in the free troposphere are frequent over Réunion, Fiji, Samoa, San Cristóbal, and Ascension [Thompson et al., 1996; 2003b; Oltmans et al., 2001; 2004; Randriambelo et al., 2003]. Reduced $\mathrm{O}_{3}$ layers often characterize the UT and TTL (tropical tropopause layer, $\sim 8-14 \mathrm{~km}$; Fueglistaler et al., 2009), where convective outflow of low- $\mathrm{O}_{3}$ BL air occurs. If $\mathrm{O}_{3}$ in the UT or TTL averages to lower concentrations than in the mid-troposphere, an "S-shape" profile results [Folkins et al., 200o].

The laminar identification (LID) method, based on $\mathrm{O}_{3}$ and potential temperature gradients [Teitelbaum et al., 1994, 1996; Grant et al, 1998; Thompson et al., 2007a; 2008], interprets persistent $\mathrm{O}_{3}$ layers in terms of two wave-types. In the tropics, Rossby waves (RW) represent horizontal displacement; these correspond to filaments of extratropical air or pollution from long-range transport. When SHADOZ profiles are analyzed with the LID technique, RW signatures appear in $<20 \%$ of the soundings [Loucks, 2007; Thompson et al., 2010]. Signatures of convectively-generated gravity waves (GW) occur 
in 40-90\% of SHADOZ soundings, depending on location and season [Thompson et al., 2010a,b]. Near the tropopause, GW are usually identified with Kelvin waves. Transient Kelvin waves have been observed in $\mathrm{O}_{3}$ over both eastern and western Pacific [Fujiwara et al., 1998; 2001].

Wave activity over the equatorial Americas has received less attention. Robust GW and RW signals were noted during the Milagro/INTEX-B/IONS-O6 (Intercontinental Transport Experiment; INTEX Ozonesonde Network Study) campaigns over Mexico City $(19 \mathrm{~N}, 99 \mathrm{~W})$ and Houston (30N, 95W) in March-May 2006 [Thompson et al., 2008], two locations that are essentially sub-tropical when springtime air parcel flows link them to central America [Fast et al., 2007]. The TC4 (Tropical Composition, Cloud, and Climate Coupling) mission in July-August 2007 offered an opportunity to characterize $\mathrm{O}_{3}$ profiles closer to the equator than the IONS-06 soundings. TC4 [Toon et al., 2010] investigated chemical transformation in convective systems and the impacts of deep convection on constituent transport, dehydration and cirrus formation. Sampling from San Jose, Costa Rica, with NASA's DC-8, WB-57 and ER-2 aircraft, was well-suited for comparisons with observations from Las Tablas, Panamá (LTP, $7.8 \mathrm{~N}, 80 \mathrm{~W}$ ), where daily soundings were made from the NATIVE (Nittany Atmospheric Trailer and Integrated Validation Experiment) mobile lab. Most TC4 flights were south of the Intertropical Convergence Zone (ITCZ), which was located at 12-13N during the experiment [Toon et al., 2010]. SHADOZ [Thompson et al., 2003a] soundings from Costa Rica (Alajuela, 10N,84W) were augmented with several launches per week from early July through 9 August 2007.

Five $\mathrm{TC}_{4}$ studies are devoted to analysis of ozone transport and wave activity. In Selkirk et al. [2010] temperature anomalies from four-times-daily radiosondes over Alajuela indicate equatorial waves in the TTL. Comparison of $\mathrm{TC}_{4}$ radiosondes and water vapor from cryogenic frost-point hygrometer readings suggests less convection than during the 2005 TCSP (Tropical Convective Systems and Processes) campaign in the same location and time of year. The free troposphere was drier in TC4 than TCSP, and $\mathrm{O}_{3}$ in the mid-upper troposphere was $\sim 35 \%$ higher in TC4 (Figures 1, 3 and 4 in Selkirk et al., 2010). Avery et al. [2010] focus on the strong anti-correlation between ozone and condensed cloud water content measured during sampling in active convection, and generalize their findings on convective redistribution of ozone with tracer composites. Convective outflow as indicated by local $\mathrm{O}_{3}$ minima and elevated lower tropospheric tracers appears to maximize at 10-11 km. Avery et al. [2010] argue that in the DC-8 
sampling region near the ITCZ, there has been about 50\% convective turnover below the TTL, with vertical transport from just above the boundary layer. In Morris et al. [2010] lower-mid tropospheric $\mathrm{O}_{3}$ within a convectively active region over the Pacific southwest of the Las Tablas (LTP) launch site on 5 August 2007 is investigated in detail. The LTP sounding for that day was caught in a strongly convective cell that bounced the balloon package up and down between 2.5-5 km; the $\mathrm{O}_{3}$ within this layer increased from 30 to 40 ppbv before the balloon ascended to the stratosphere. Petropavlovskikh et al. [2010], analyzing the 17 July 2007 DC-8 flight, find that influences on $\mathrm{O}_{3}$ near the TTL are a mixture of convection and advection, the latter including extra-tropical air, some of it possibly of stratospheric origins. The lowest $\mathrm{O}_{3}$ layer occurred at 9-11 km, but low- $\mathrm{O}_{3}$ signatures were also recorded by the UV-DIAL instrument at 2-4 km and $13 \mathrm{~km}$.

As insightful as the above investigations are, none systematically examines dynamic influences in ozone structure in the free troposphere and LS day-by-day during TC4. That is the purpose of the present study. Using the full record of Alajuela (ACR) and Las Tablas $\mathrm{O}_{3}$ soundings (Section 2), the following analyses are performed:

1) Mean $\mathrm{O}_{3}$ profiles are determined and day-to-day variability is examined in curtains of $\mathrm{O}_{3}$ mixing ratio and in integrated $\mathrm{O}_{3}$ column amounts.

2) Ozone budgets based on LID and expressed as amounts affected by GW and RW provide a consistent framework for examining dynamic influences over the course of TC4. The climatology of wave signatures at LTP and ACR is compared to those at Paramaribo $(5.8 \mathrm{~N}, 55 \mathrm{~W})$ and San Cristóbal (0.92S,90W) sondes, long-term SHADOZ stations also in the equatorial Americas (Section 3.1).

3) Case studies of soundings and ancillary aircraft measurements are used to corroborate wave designations, with convection for GW and stratospheric influences or pollution for RW (Section 3.2). One episode is among those analyzed by Avery et al. [2010] and Morris et al. [2010]. Others were chosen to illustrate contrasting impacts.

4) In Section 4 context for the $\mathrm{TC}_{4}$ observations is given by June-July-August (JJA) Costa Rican sondes in 2006, and the 9-year SHADOZ record [Thompson et al., 2003a,b] at Paramaribo and San Cristóbal. Specifically we ask:

$>$ How does tropospheric $\mathrm{O}_{3}$ over LTP and ACR in 2007 compare to $\mathrm{JJA} \mathrm{O}_{3}$ over Costa Rica (Heredia site near Alajuela) in 2006, when an El Niño affected the eastern Pacific [Arguez, 2007]? How do LTP and ACR $\mathrm{O}_{3}$ during TC4 compare to $\mathrm{O}_{3}$ over San Cristóbal in 2007? 
$>$ How does $\mathrm{O}_{3}$ over the equatorial Americas in $\mathrm{TC}_{4}$ compare to the 1999-2006 record? Indices based on GW activity are used to quantify interannual variability.

\section{Experimental. Observations and Methods of Analysis.}

\section{$2.1 \quad$ Ground \& Aircraft}

Continuous surface $\mathrm{O}_{3}$ measurements at Las Tablas $(7.8 \mathrm{~N}, 8 \mathrm{oW})$ were made during the period 13 July to 10 August 2007 from the NATIVE mobile lab that also included an ozonesonde ground station. The surface $\mathrm{O}_{3}$ was measured with a TECO Model $49 \mathrm{C}$ ozone analyzer, along with carbon monoxide (TECO Model 48CTL), NO and $\mathrm{NO}_{\mathrm{y}}$ (TECO Model $42 \mathrm{CY}$ ), $\mathrm{SO}_{2}$ (TECO Model 43C-TLE) and particle size distribution (Scanning Mobility Particle Sizer). All data can be viewed at $<$ http://ozone.met.psu.edu/NATIVE/ measurements.html>. Calibrations of $\mathrm{O}_{3}, \mathrm{CO}$, and $\mathrm{SO}_{2}$ were made prior to and directly after the campaign with instrument grade gases (Airgas, Inc.). Calibration of $\mathrm{NO}$ and $\mathrm{NO}_{\mathrm{y}}$ was performed daily with instrument grade NO (Airgas, Inc.). Catalytic conversion efficiency tested before and after $\mathrm{TC}_{4}$ remained close to $100 \%$. 2.2 Ozone Profiles and P-T-U Profiles

All ozone profile data analyzed here were taken with electrochemical concentration cell (ECC) instruments coupled with standard radiosondes, as described in Thompson et al. [2003; 2007a]. Coordinates of LTP, ACR and the SHADOZ sites referred to here appear in Table 1, along with details of the sondes used. At Las Tablas, the $0.5 \% \mathrm{KI}$ buffered solution with ENSCI ozonesondes is a combination that optimizes tropospheric and stratospheric $\mathrm{O}_{3}$ measurements [Smit et al., 2007; Thompson et al., 2007b; Deshler et al., 2008]. Vaisala radiosondes, Model RS-80, were used to collect P-T-U data. For nine of the 25 LTP soundings during $\mathrm{TC}_{4}$ the humidity data are unreliable above $\sim 300$ $500 \mathrm{hPa}$ due to suspected sensor icing. Ozone profiles from LTP are viewable at $<$ http://ozone. met.psu.edu/Panama_Data/index.html $>$. Each ozonesonde is calibrated according to standard procedures prior to launch; all LTP sondes were also compared to the TECO $\mathrm{O}_{3}$ for 5-10 minutes pre-launch; agreement is within the stated precision of each technique (5\%; Figure 1 in Morris et al., 2010).

Ozone over Alajuela was measured by ENSCI ECC sondes with $1 \%$ KI with reduced (o.1\%) buffer (Table 1); RS-8o radiosondes with a cryogenic frost-point hygrometer were used for P-T-U. At both ACR and LTP, most launches took place in early afternoon local time to capture Aura [Schoeberl et al., 2006], Aqua and CALIPSO satellite overpasses 
[Toon et al., 2010]. Images and data for all Costa Rican (late 2005 start), Paramaribo (1999-present) and San Cristóbal (1999-present) ozonesonde and P-T-U profiles are available at $<$ http://croc.gsfc.nasa.gov/shadoz $>$ and at the World Ozone and Ultraviolet Data Centre, <http://woudc.org $>$.

Aircraft data used most often in analysis of the soundings are: $\mathrm{O}_{3}$ from the the Cloud Physics Lidar (CPL) and Cloud Radar System (CRS) on the ER-2 [McGill et al., 2004; Hlavka et al., 2010]. Regional cloud and convective information comes from meteorological analyses and GOES imagery, as archived by Toon et al. [2010].

\section{$2.3 \quad$ Ancillary Data}

As for IONS-04 [Thompson et al., 2007a] and IONS-06 [Thompson et al., 2008], tracers for $\mathrm{O}_{3}$ origins include: (1) RH from the radiosonde P-T-U profiles; (2) Ertel's potential vorticity (pv; $1 \mathrm{pvu}=10^{-6} \mathrm{~m}^{2} \mathrm{~s}-1 / \mathrm{K}$ ) computed from the Goddard Earth Observing System Assimilation Model (GEOS-version 4; Bloom et al., 2005); (3) forward and backward air-parcel trajectories for each launch location and date, calculated with the kinematic version of the GSFC trajectory model [Schoeberl and Sparling, 1995] using GEOS meteorological fields at a 1x1-degree grid. Lightning imagery is also used to describe potential $\mathrm{O}_{3}$ influences, as are absorbing aerosol data from OMI, trajectoryenhanced aerosol-exposure images and $\mathrm{OMI} \mathrm{NO}_{2}$ amounts. All back-trajectories in the $\mathrm{TC}_{4}$ region, aerosol and lightning data and trajectory-mapped exposure products are at the GSFC TC4 website: <http://croc.gsfc.nasa.gov/tc4 $>$. In selected cases, additional trajectories were run with the NOAA Hysplit model (Draxler and Rolph, 2003).

\section{$2.4 \quad$ Analysis for Wave Influences}

In the LID (Laminar Identification; Thompson et al., 2007a; 2008) technique, $\mathrm{O}_{3}$ and potential temperature $(\theta)$ laminae, as described in Teitelbaum et al. $[1994 ; 1996]$ and Pierce and Grant [1998] are used to identify RW and GW signatures as illustrated in Figure 1. The method is described as follows:

1) For each sounding, the $\mathrm{O}_{3}$ and $\theta$ laminae are isolated through normalization to running means. A boxcar smoothing over $2.5 \mathrm{~km}$ is used to isolate each lamina. Larger and smaller ranges (from 0.5 to $2.5 \mathrm{~km}$ ) have been tested with little difference in laminar statistics. Normalized $\mathrm{O}_{3}$ is the solid line in Figure 1; the $\theta$ deviations are signified by the dotted line. Because the ozone mixing ratio 
precision is $5 \%$ in most of the region of interest, only laminae representing a deviation of $\geq 10 \%$ are included in the analysis (red vertical lines in Figure 1).

2): Correlations between $\mathrm{O}_{3}$ and $\theta$ gradients are compared to identify GW and RW. Where the correlations (as in dashed line, Figure 1) exceed 0.7 GW (light green) is defined, based on the reasoning that such correlation between the two quantities signifies a vertical disturbance. Conversely, when horizontal motion affects $\mathrm{O}_{3}$, it is poorly correlated with $\theta$ and RW is specified. We adopt the practice of Pierce and Grant [1998] and Teitelbaum et al., 1994], setting the RW limit for anticorrelation at \pm 0.3 , corresponding to light blue sections in Figure 1. This is a fairly conservative criterion; see Thompson et al. [2007a] for sensitivity studies.

Two analyses are performed with the LID results. First, for an ensemble of soundings, wave frequencies at a given altitude are calculated from the percentage within a sample set that have laminae designated as RW or GW. Second, for each sounding, the contributions of RW and GW above the boundary layer (BL) to the tropopause or to $20 \mathrm{~km}$ are computed by integrating the amount of $\mathrm{O}_{3}$ within a given layer and adding up all the RW and GW segments. Thus, "tropospheric ozone" amounts in this paper are actually free tropospheric column amounts, above a BL top that varies from $1.2 \mathrm{~km}$ (San Cristóbal) to $1.8 \mathrm{~km}$ (Paramaribo). The BL top is determined by taking the most negative second derivative of $\theta$ with respect to altitude, between 0.4 and $2.5 \mathrm{~km}$ [Yorks et al., 2009]. Dobson Units (DU) are used; one DU $=2.69 \times 10^{16} \mathrm{~cm}^{-2}$. The amount of $\mathrm{O}_{3}$ within the column not identified with RW or GW is labeled “other" in the budgets.

For determination of tropospheric LID $\mathrm{O}_{3}$ budgets (Section 3), an ozonopause definition of tropopause is employed (white dots, Figure 2; using the method of Browell et al., 1996). This technique, in which $\mathrm{O}_{3}$ gradients are approached from the stratosphere, falls closer to the cold-point tropopause than the ozonopause of Selkirk et al. (2010; their Figure 2, from Alajuela soundings). Thompson et al. [2007a] showed that tropospheric $\mathrm{O}_{3}$ columns can differ significantly under certain conditions, depending on the use of $\mathrm{O}_{3}$ or thermal tropopause. Such occurrences are infrequent in mid-latitudes $(<10 \%$ in IONS-04 or IONS-06 soundings) and are negligible in TC4, where Selkirk et al. (2010) showed that the thermal tropopause and chemical tropopause, based on either water vapor from frostpoint hygrometry or $\mathrm{O}_{3}$ mixing ratios, was consistently at $350-355 \mathrm{~K}$ (147 hPa, $14.2 \mathrm{~km}$ ); 
the cold-point tropopause was always $370-378 \mathrm{~K}(16-17 \mathrm{~km})$. For a 1-2 km difference in thermal tropopause and the higher ozonopause, the $\mathrm{O}_{3}$ budget might vary 2-3 DU.

\subsection{Overview of Ozone Profiles over LTP and ACR}

From time-series of $\mathrm{O}_{3}$ mixing ratio over Las Tablas and Alajuela (Figure 2) the following features emerge: (1) Roughly $10 \%$ more $\mathrm{O}_{3}$ is found in the LTP BL than at ACR due to pollution from Panamá City and occasionally from South American biomass fires. (2) The TTL extends lower over LTP than over ACR. It is customary to assume that when the free tropospheric segment of an ozone profile resembles BL concentrations that convective redistribution has taken place [Kley et al. 1996; Thompson et al., 1997; Newell et al., 1999, Folkins et al., 2006]. Given typical BL concentrations of 20-25 ppbv at the two sites, Figure 2 suggests that there are fewer episodes of high-altitude convection over LTP than ACR (blue shade, 12-14 km), although that inference may be an artifact of LTP 11-14 km (Figure 3a) than LTP (Figure 3b; cf Figure 13 in Avery et al., 2010), giving a slight "S" shape in the $\mathrm{ACR} \mathrm{O}_{3}$ profile. The " $\mathrm{S}$ " is similar to Pacific SHADOZ profiles (Folkins et al., 2000; 2006; cf Kley et al., [1996]) and to IONS-06 soundings (<http:// croc.gsfc.nasa.gov/intexb/ionso6.html>) over Mexico City (19N, 99W) that detected the highest $\mathrm{O}_{3}$ at 8-9 km and minimum $\mathrm{O}_{3}$ at 12-14 km (Thompson et al., 2008; Fig 5).

Convective signatures in DC-8 sampling, registered as locally minimum ozone in profiles from the FASTOZ instrument, were concentrated between 10 and $11 \mathrm{~km}$ [Avery et al., 2010]. Elevated lower tropospheric tracers such as methyl hydrogen peroxide and organic bromine-containing constituents (Figures 13-15 in Avery et al., 2010) occur coincidentally with the lower ozone. Mean DC-8 $\mathrm{O}_{3}$ profiles and the soundings (Figure 3a) are somewhat divergent. This is not surprising given that the sondes are at fixed locations whereas the DC-8 deliberately sampled in the vicinity of active convection.

\subsection{Overview of Wave Signatures in the Sondes}

Figure 4a shows that the $\mathrm{O}_{3}$ labeled GW is concentrated throughout the TTL and lower stratosphere over both LTP and ACR, with frequencies similar to those at the Paramaribo and San Cristóbal SHADOZ sites (Figure 4b). The latter depicts wave frequencies averaged for 1999-2007, which are nearly identical to June-July-August statistics. The waves in Figures $\mathbf{4 a} \mathbf{a}, \mathbf{b}$ are similar to other SHADOZ tropical [Thompson et al., 2010a,b] and northern hemisphere subtropical locations (Figure 4 in Thompson et al., 2008). As in Thompson et al. [2010a,b], the GW signal in the TTL is more frequent at 
the station that is closer to the equator (Las Tablas and San Cristóbal, respectively, in Figures 4a and 4b). However, ACR has a higher GW frequency at 3 and $6 \mathrm{~km}$, where convective outflow often occurs (Section 3.3). Ozone associated with GW is $15-20 \%$ of the tropospheric column (Table 2). In half the days with $\mathrm{TC}_{4}$ soundings at both LTP and ACR, LTP $\mathrm{O}_{3}$ at 3-6 km is 40-50 ppbv vs $~ 30$ ppbv over ACR (cf Figure 3 mean $\mathrm{O}_{3}$ profiles). Thus, column tropospheric $\mathrm{O}_{3}$ is $\sim 30 \%$ higher over LTP than ACR (Table 2).

\subsection{Case Studies with Varying Convective and Wave Influence}

Days with coincident launches at LTP and ACR (Figure 5a) offer an opportunity to compare ozone profiles at the two sites and to use $\mathrm{TC}_{4}$ aircraft data, satellite imagery and meteorological products to interpret convective and wave influences. On all dates of column $\mathrm{O}_{3}$ to $20 \mathrm{~km}$ designated as GW. The TC4 period started with a phase characterized by active convection over the Costa Rica-Panamá region and the adjacent Pacific (Section 3.3.1); this corresponds to the left-most section relative to the vertical dashed line in Figures $\mathbf{5 b}$,c. This is corroborated by satellite and aircraft imagery in flights through 22 July 2007 [Toon et al., 2010]. In a second phase, from 23 July through 2 August (Section 3.3.2), between the two dashed lines in Figures $\mathbf{5}$ b,c, TC4 aircraft continued to sample convection but it was less active at ACR and LTP. The fraction of total $\mathrm{O}_{3}$ designated $\mathrm{GW}$ declined in most soundings (Figures $\mathbf{5} \mathbf{b}, \mathbf{c}$ ), as the GW-affected segments in $\mathrm{O}_{3}$ profiles retreated from the troposphere to above $17 \mathrm{~km}$. The amount of column $\mathrm{O}_{3}$ affected by RW increased compared to the pre-24 July period. More active convection resumed in a third phase (Section $\mathbf{3 \cdot 3 \cdot 3}$ ) after 2 August, when targeted sampling by the ER-2, DC-8 and WB-57 took place [Toon et al., 2010]. In the following sections episodes illustrative of the three phases are examined to verify the link between the GW designation and convective activity and the relationship of RW to extra-tropical and/or pollution influences.

\subsubsection{3-22 July 2007: Active Convection and Elevated GW}

13 July. Convective activity at LTP and ACR, as given by GW amount to $20 \mathrm{~km}$, is similar (Figure 5a). The fraction of $\mathrm{FT} \mathrm{O}_{3}$ influenced by $\mathrm{GW}$ is similar in both cases $\left(\sim 20 \%\right.$; Figures 5b,c). A typical pair of profiles (Figure 6a) shows that the ACR $\mathrm{O}_{3}$ concentration averages $\sim 40$ ppbv from the surface to the tropopause (14-15 km), whereas $\mathrm{O}_{3}$ in the upper troposphere over LTP exceeds 50 ppbv. $\mathrm{BL} \mathrm{O}_{3}$ at LTP is less than at ACR. The RH profiles have considerable structure, with moister air over LTP than ACR. 
Evidence for convection over ACR comes from the DC-8 flight from California to San Jose, Costa Rica, on 13 July 2007. The last $100-150 \mathrm{~km}$ of the flight encompassed a descent near ACR at $\sim 2100$ UTC, after the aircraft had crossed the ITCZ. The DC-8 uv-DIAL image of $\mathrm{O}_{3}$ (Figure 6b) captures the morphology of convective impact throughout the FT and TTL. North of the ITCZ (northern edge at $13 \mathrm{~N}$ ), the FT was penetrated by pollution $\mathrm{O}_{3}$ ( $>80 \mathrm{ppbv}$ ) and aerosols traced to biomass fires interacting with convection. South of the ITCZ, just before descent, FT $\mathrm{O}_{3}$ dropped to 40-50 ppbv, except for a localized $\mathrm{O}_{3}$ minimum (<30 ppbv) around $10 \mathrm{~km}$ (Figure 6b), similar to $\mathrm{FT} \mathrm{O}_{3}$ structure over ACR (Figure 6a), and to the DC-8 $\mathrm{FASTOZ} \mathrm{O}_{3}$ during descent. Note a very thin layer of low ozone at $13 \mathrm{~km}$ in the uv-DIAL image, corresponding to an altitude with low $\mathrm{O}_{3}$ over ACR. A similar low- $\mathrm{O}_{3}$ "bubble" sampled on 17 July 2007 is discussed by Petropavlovskikh et al., 2010s. The uv-DIAL aerosols (not shown) corresponding to Figure $6 \mathbf{b}$ indicate a "clean" FT south of the ITCZ except for thin cirrus at the tropopause, consistent with the soundings. Convective indicators, elevated CO, methyl-hydrogen peroxide, lightning NO, ultrafine particles (not shown; see flight report at < $\underline{\text { http://espo. nasa.gov/tc4/docs }>\text { ), }}$ penetrated south of the ITCZ. These pollutants came from north of the ITCZ. Interhemispheric transport during convection is well known over the Atlantic [Jonquières et al., 1998; Thompson et al., 2000; Edwards et al., 2003].

On 13 July (Figure 5b,c) about half the tropospheric $\mathrm{O}_{3}$ over both LTP and ACR corresponds to RW. The corresponding segments in the ACR profile (Figure 6a) are locally enhanced in $\mathrm{O}_{3}$ and reduced in $\mathrm{RH}$, suggesting extra-tropical influence. This is a good example of a sounding that captures both advective and convective signals.

22 July. On this day there is more $\mathrm{O}_{3}$ in the TTL and LS identified as GW over LTP than ACR (Figures 5a, 7a). There is relatively little tropospheric $\mathrm{O}_{3}$ associated with GW over either one (Figures 5b,c). A convective contrast between LTP and ACR is evident in satellite imagery (see ER-2 flight report for 22 July 07 at < http://espo. nasa.gov/tc4/docs $>$ ). When the ER-2 sampled near LTP on 22 July, the cloud and precipitation CPL-CRS imagery (Figure 7b) indicated several levels of convective outflow. For example, there is cirrus with a 13.5-14 km cloud top, coinciding with a GWlabeled segment in the LTP sounding, right above a localized $\mathrm{O}_{3}$ minimum (black profile, Figure 7a). The CPL-CRS indicates another cloud outflow layer at $4 \mathrm{~km}$. This region is not designated as $\mathrm{GW}$ although there is a local $\mathrm{O}_{3}$ minimum at $4 \mathrm{~km}$ and relatively high $\mathrm{RH}$. From 2-5 km the designation is $\mathrm{RW} ; \mathrm{O}_{3}$ is $60 \%$ greater than at the surface, suggesting possible pollution transport. Surface ozone at LTP, measured in NATIVE on 22 July, 
averaged 15 ppbv (Figure 8a) but the moderately high CO mixing ratio, 135 ppbv,

supports an interpretation of pollution (Figure $\mathbf{8 b}$ ).

3.3.2. 23 July-2 August: Elevated RW

During the period 23-28 July most sonde launches were at LTP. At both sites, the soundings from 23 July to 2 August displayed fractionally higher $\mathrm{RW} \mathrm{O}_{3}$ segments in the troposphere (Figure 5b,c). An example appears in Figure 9a. The RW signal over LTP extends from 2 to $17 \mathrm{~km}$ on 2 August, except for a 2-km region, and there is no GW segment. ACR displays convective influence in terms of GW only from 11-15 km. An RW segment from 5-10 km coincides with a dry layer from 4-9 km; this is suggestive of air from the extra-tropics. Even though convection picks up on 3 August, remnants of the RW feature persist over both sites on that day (Figure $\mathbf{9 b}$ ).

During the period of greater RW, there were also changes in surface $\mathrm{O}_{3}$ and $\mathrm{CO}$ at Las Tablas (see NATIVE data in Figure 8). On 23 July a normal diurnal $\mathrm{O}_{3}$ cycle was observed, with a near-zero nocturnal minimum. LID analysis for the 23 July sounding at LTP was not valid, indicating active transition and no stable layers. However, on 24 July the $\mathrm{O}_{3}$ minimum rises to $\sim 15 \mathrm{ppbv}$. This causes daily mean $\mathrm{O}_{3}$ to increase from $17 \mathrm{ppbv}$ on 23 July to 25 ppbv on 24 July. At this time, CO dropped below 90 ppbv (Figure 8 b), one of the lowest values at NATIVE during TC4.

\subsubsection{3-10 August: Return of Active Convection. Elevated GW}

3 August. The fractions of GW and RW tropospheric segments over Las Tablas and Alajuela are nearly the same (Figures 5b,c) and the wave structures are similar (Figure 9b). Over LTP the GW signal that was absent on 2 August returns at 13-20 km (Figure 9b). The DC-8 and ER-2 sampled not far from LTP near active convection (refer to GOES image with flight tracks for all three aircraft on 3 August; Figure 16 in Toon et al. [2010]). The DC-8 profiles in Figure 10a were taken over NATIVE from 1705-1735 UTC during the convective period that was sampled less than $50 \mathrm{~km}$ away by the ER-2; the LTP launch took place at 1741 UTC. The upper of two $\mathrm{O}_{3}$ minima over LTP (10-15 km, Figure 9b), corresponds to cloud outflow recorded by satellite imagery (not shown) and to cirrus in the ER-2 CPL-CRS product (Figure 10b) at 13-15 km. A second $\mathrm{O}_{3}$ minimum with elevated $\mathrm{CO}$ at 5-6 km (Figure 10a) is also located at a cloud outflow layer (lower bar arrow in Figure 10b). Over ACR, $\mathrm{O}_{3}$ mixing ratios averaged $>80$ ppbv in the $6-13 \mathrm{~km}$ segment (Figure 9b). Above $8 \mathrm{~km}$, the RH drops off sharply, suggesting extra-tropical air. The elevated $\mathrm{O}_{3}$ coincides with a mostly RW segment that brackets the tropopause, which is $1.5 \mathrm{~km}$ higher over LTP than ACR (Figure 2). 
5 August. During the period 3-5 August there was a sharp transition in the LTP and ACR profiles that is reflected in the $\mathrm{O}_{3}$ budgets (Figures 5a-c); the $\mathrm{GW} \mathrm{O}_{3}$ budgets to $20 \mathrm{~km}$ are nearly identical over the two stations on 4 August (Figure 5a). The upper tropospheric $\mathrm{O}_{3}$ mixing ratios decline over both sites, from a mean of $\sim 75 \mathrm{ppbv}$ on 3 August to 45 ppbv on 5 August (Figures 9b,c); during the transition, LTP free tropospheric $\mathrm{O}_{3}$ declines to $22 \mathrm{DU}$ on 4 August, the lowest $\mathrm{O}_{3}$ column in the $\mathrm{TC}_{4}$ period (Figure 5b). From 4 to 5 August there are further transitions in vertical $\mathrm{O}_{3}$ structures over ACR and LTP (Figure 9c). The GW signal that starts over LTP (ACR) at $12 \mathrm{~km} \mathrm{(11}$ $\mathrm{km}$ ) on 4 August (not shown) retreats to $15 \mathrm{~km}$ on 5 August. Over Las Tablas a several-km thick layer that is 20 ppbv above background coincides with RW (Figure 9c; also Figure 1). DC-8 aircraft sampling near LTP on 5 August confirmed the possibility of extratropical origins at 8-10 km, where $\mathrm{O}_{3}$ mixing ratios were 50-70 ppbv in a relatively dry layer [Avery et al., 2010]. However, just above this layer, at $11 \mathrm{~km}$, the DC-8 noted cleaner than usual conditions, signifying convective outflow of marine boundary layer air (upper outflow on Figure 10c). Near the surface, the DC- 8 detected pollution due to biomass fires (Flight notes at $<\underline{\text { http://www.espo.nasa.gov/tc4/flightDocs.php }>\text { ). }}$

The 5 August ozonesonde launch at LTP (1505 UTC) was timed for nearby DC- 8 spiral ( 1540 UTC) and ER-2 sampling of convective cells to the southwest (Figure 10c; cf Figure 19 in Toon et al., 2010). Between $2.5 \mathrm{~km}$ and $5.1 \mathrm{~km}$, the sonde bounced up and down five times within a convective cell while $\mathrm{O}_{3}$ concentrations increased by $\sim 10$ ppbv. Morris et al. [2010] use satellite imagery, lightning data, radar and $\mathrm{OMI} \mathrm{NO}_{2}$ maps, along with DC-8 measurements to demonstrate that lightning NO production is responsible for much of the increase. The lower outflows in Figure 10c correspond to the region of the bouncing sonde. The profile in Figure 9c is based on the final sonde ascent from 2.5 to $5.1 \mathrm{~km}$; the GW signal is not detected.

\section{Waves in the Equatorial Americas: 1999-2007. TC4 in Context.}

A perspective for interpreting convective influence over LTP and ACR is provided by wave frequencies over Paramaribo and San Cristóbal (Figure 4b), SHADOZ sites operating since 1999 [Thompson et al., 2003a,b]. The amplitudes of individual layers and wave structure at Paramaribo and San Cristóbal resemble those for LTP and ACR (Figure 1) as do the structure of the GW frequencies at LTP and ACR (Figures $4 \mathbf{a}, \mathbf{b}$ ). Similar GW structure appears over equatorial Indian Ocean sites, eg Watukosek, Kuala Lumpur, that display the highest annually averaged GW frequency, 60\% [Thompson et al., 2010a]. The higher GW frequency at San Cristóbal leads to a larger GW fraction of tropospheric $\mathrm{O}_{3}$ 
(Figure 11). Although the tropospheric $\mathrm{O}_{3}$ column averaged $25 \mathrm{DU}$ in 2007, compared to 28 DU for LTP, $25 \%$ of $\mathrm{O}_{3}$ is GW-affected at San Cristóbal compared to 15\% at LTP (Table 2). $\mathrm{TC}_{4}$ was timed for the onset of the sub-tropical convective season and the North American monsoon. Figure 4c, a summary of monthly averaged GW over Paramaribo, shows that JJA has about half the maximum GW frequency, typically a December occurrence.

An interannual view of ozone budgets and convective influence appears in Figure 11, where the mean JJA tropospheric $\mathrm{O}_{3}$ column (with segments for RW and GW) is displayed for Costa Rica (2006 only), Paramaribo and San Cristóbal from 1999-2007. At San Cristóbal, 2006 is a low- $\mathrm{O}_{3}$ year compared to the six others, possibly due to a moderate El Niño [Arguez, 2007]. In the eastern Pacific, El Niño tends to enhance convective activity, mixing lower $\mathrm{O}_{3}$ air from the $\mathrm{BL}$ throughout the troposphere. [Logan et al., 2008]. The GW-affected tropospheric ozone amount in 2006 is only slightly lower than normal over San Cristóbal but the total tropospheric column dropped from a mean 22-23 DU (1999-2005; Figure 11) to 18 DU so the GW fraction is magnified. At Heredia (20 km away) 2006 tropospheric $\mathrm{O}_{3}$ is lower than over ACR in 2007 (Figure 11).

General meteorological conditions at Paramaribo (6N), Panamá ( $8 \mathrm{~N})$, and Alajuela $(10 \mathrm{~N})$ are similar, with the ITCZ migrating over each. The SHADOZ wave climatology [Loucks, 2007; Thompson et al., 2010] shows GW frequency diminishing with increasing to $20 \mathrm{~km}$ denoted as GW, provides a quantitative comparison of site-to-site and interannual variability. GWI is larger at San Cristóbal than Paramaribo until 2004 when data gaps at San Cristóbal compromise the record. The gaps also preclude conclusive linkage of GWI to signals associated with an El Niño.

\section{Summary}

During TC4, in July and early August 2007, ozonesondes and radiosondes were launched several times/week at Alajuela, Costa Rica $(10 \mathrm{~N}, 84 \mathrm{~W})$ to characterize convective influences in the tropical tropopause layer (TTL). At Las Tablas, Panamá (7.8N, 8oW), a coastal site $300 \mathrm{~km}$ southwest of Panamá City, $\mathrm{O}_{3}$ profiles from daily sondes, surface $\mathrm{O}_{3}$, $\mathrm{CO}$ and other tracers are analyzed. Laminar identification provides a systematic approach to classifying wave signatures in sounding data, giving a statistical perspective on the TC4 period and the longer-term SHADOZ sounding record at Paramaribo and San Cristóbal. The findings are summarized: 
- GW influences, possibly due to semi-permanent Kelvin waves in the TTL and lower stratosphere (cf Grant et al., 1998; Thompson et al., 2010a) appeared in 50\% (40\%) of Las Tablas (Alajuela) sondes. The GW structure and frequency are similar to those over SHADOZ stations at San Cristóbal and Paramaribo.

- $\quad$ On average there is $35-40 \%$ more tropospheric column $\mathrm{O}_{3}$ at LTP than ACR during $\mathrm{TC}_{4}$ and $20 \%$ more at LTP than at San Cristóbal, a remote marine station, $1400 \mathrm{~km}$ southwest of LTP. June-July-August $\mathrm{O}_{3}$ budgets at Paramaribo and San Cristóbal suggest that 2007 was a "typical" year in terms of tropical equatorial $\mathrm{O}_{3}$ amount and convective activity expressed in GW frequency. During 1999-2006, Paramaribo and San Cristóbal display $\mathrm{O}_{3}$ column amounts and convective influence that bracket the $\mathrm{TC}_{4}$ ACR and LTP values.

Classification of wave types through LID is validated through case studies in which aircraft observations support interpretation of convective influences (with the GW designation) and extra-tropical impact, corresponding to RW. Laminae of low- $\mathrm{O}_{3}$ surface air convectively injected into the free troposphere are detected by LID, frequently interleaved with the richer- $\mathrm{O}_{3}$ layers; subtle day-to-day variations are captured. The pattern of convection inferred from LID is consistent with the meteorological evolution of the campaign [Toon et al., 2010]. The early part of TC4, to 22 July 2007, was characterized by persistent GW throughout the free troposphere and TTL. After a less active period, from 23 July until approximately 2 August, with lower GW signals and greater RW, GW increased in frequency along with convection.

Sonde and aircraft data established further the convection-GW linkage and demonstrated the prevalence of extra-tropical laminae interleaved with layers from convective outflow throughout the equatorial Americas. In terms of TC4 objectives, our analysis of ozone structure strengthens the case for convection as a dominant mechanism for water vapor transport and cirrus formation in the TTL. The persistence of higher- $\mathrm{O}_{3}$ laminae in the troposphere requires further investigation to determine the extent to which these layers are remnants of extra-tropical filaments or associated with localized equatorial waves.

Acknowledgments. We are grateful to NASA's Upper Air Research Program and Aura Validation (M. J. Kurylo; K. W. Jucks) that sponsored the Las Tablas and Alajuela TC4 soundings and ground-based measurements at Las Tablas. These programs, with NOAA support, also sponsor SHADOZ at Costa Rica and San Cristóbal. The Paramaribo station is sponsored by KNMI and the Suriname Meteorological Department. Additional analysis support came from NASA's Tropospheric Chemistry Program (J. H. 
Crawford, J. A Al-Saadi). Las Tablas measurements with the NATIVE trailer were assisted by A. Pino and L. Jordan (University of Panamá); A. M. Bryan and D. Lutz (Valparaiso Univ); Z. Chen and J. L. Tharp (PSU). Costa Rican launches were made by UNA students K. Cerna, V. H. Beita, D. Gonzalez. Thanks to Mission Scientists M. R. Schoeberl and P. A. Newman for flight notes and to K. E. Pickering for discussing lightning data. Thanks to EAB, BvdW, AOG (PSU) for analysis.

\section{APPENDIX. ABBREVATIONS AND ACRONYMS}

$\mathrm{ACP}=$ Alajuela, Costa Rica $(10 \mathrm{~N}, 84 \mathrm{~W})$

$\mathrm{BL}=$ Boundary Layer, here determined from radiosondes (Yorks et al. 2009)

CALIPSO = Cloud-Aerosol Lidar and Infrared Pathfinder Satellite Observation

$\mathrm{CPL}=$ Cloud Physics Lidar (ER-2 instrument)

CRS $=$ Cloud Radar System (ER-2 instrument)

$\mathrm{DU}=$ Dobson Unit $\left(1 \mathrm{DU}=2.69 \times 10^{16} \mathrm{~cm}^{-2}\right)$

$\mathrm{ECC}=$ Electrochemical Concentration Cell (ozonesonde type)

FT $=$ Free Troposphere

GOES = Geostationary Operational Environmental Satellites

GSFC $=$ Goddard Space Flight Center

GWI = Gravity Wave Index

INTEX = Intercontinental Transport Experiment (-A, 2004; B, 2006)

IONS = INTEX Ozonesonde Network Study <http://croc.gsfc.nasa.gov/intex/ions.html; ... intexb/ionso6>

ITCZ = Intertropical Convergence Zone

JJA = June-July-August

LTP = Las Tablas, Panamá $(7.8 \mathrm{~N}, 80 \mathrm{~W})$

NASA $=$ National Aeronautics and Space Administration

$\mathrm{OMI}=$ Ozone Monitoring Instrument

P-T-U = Pressure-Temperature-Humidity

RH = Relative Humidity

RWI = Rossby Wave Index

SHADOZ = Southern Hemisphere Additional Ozonesondes <http://croc.gsfc.nasa.gov/shadoz>

SOWER = Stratospheric Ozone and Water Vapor in Equatorial Regions

$\mathrm{TC}_{4}=$ Tropical Composition, Clouds and Climate Coupling (2007)

<http://espo.nasa.gov/tc4 $>$

TCSP = Tropical Convective Systems and Processes (Costa Rica, 2005)

TTL = Tropical Tropopause Layer (sometimes tropopause transition layer)

UV-DIAL = Ultraviolet Differential Airborne Lidar [Laser Detection and Ranging]

Table 1. Stations for which data are used. Further technical details given in Table A-1 in Thompson et al. (2003a) and in Thompson et al. (2007b).

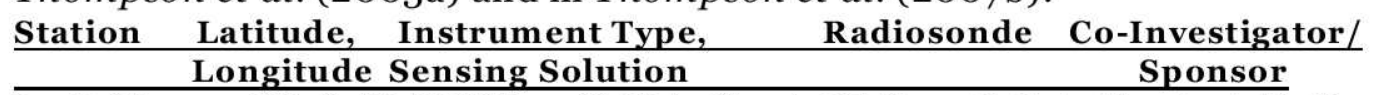

Las Tablas $7.8 \mathrm{~N}, 80 \mathrm{~W}$ ENSCI, 0.5\% KI, buffered RS-80-15N G. A. Morris, A. M. Thompson

Heredia/Alajuela, 10.0N,84 W ENSCI, 1\% KI, RS-80\& H. Vömel; J. Valverde Canossa

buffered Cryogenic Frost-point hygrometer

San Cristóbal $\quad 0.92 \mathrm{~S}, 89.6 \mathrm{~W}$ ENSCI $2 \%$ unbuffered RS-80 H. Vömel. INAMHI (National

to $2006 ; 1 \%$, reduced Inst. of Hydrology and

buffer, 2006-

Meteorology of Ecuador), M. V. A.

Reyes [Johnson et al., 2002; Thompson et al., 2007b]

Paramaribo $5.8 \mathrm{~N}, 55 \mathrm{~W} \quad$ SPC, $1 \%$ KI buffered RS-80 to 2005 G. Verver \& Met. Service RS-92, 2005- Suriname [Peters et al., 2003; Fortuin et al., 2006] 
Table 2. Free tropospheric ozone columns during June-July-August 2007. ACR mean omits 28 July sounding where data ended below the tropopause.

\begin{tabular}{|c|c|c|c|c|}
\hline Station & $\mathrm{GWO}_{3}$ & $\mathrm{RWO}_{3}$ & Other $\mathrm{O}_{3}$ & Total \\
\hline ACR - DU & 2.9 & 8.2 & $9 \cdot 3$ & 20.4 \\
\hline ACR - \% & 14 & 40 & 46 & 100 \\
\hline LTP - DU & 3.94 & 13.2 & 10.8 & 28 \\
\hline LTP - \% & 15 & 47 & 38 & 100 \\
\hline San Cris.- DU & $5 \cdot 5$ & 7.5 & 12 & 25 \\
\hline San Cris.- \% & 24 & 28 & 48 & 100 \\
\hline
\end{tabular}

\section{References}

Arguez, A., ed. (2007): State of the climate in 2006. Bull. Am. Meteor. Soc, 88, S1-S135. Diskin, R. Gao, P. Lawson, M. McGill, D. Rogers, G. Sachse, R. Salawitch, E. Scheuer, K. Severance, A. M. Thompson, C. Trepte, P. Wennberg, J. Ziemke, (2010) Convective distribution of tropospheric ozone and tracers in the central American ITCZ Region: Evidence from observations during TC4, J. Geophys. Res., doi: 10.1029/2009 JDo13450, in press. Manuscript available at TC4 website. Contact btoon@lasp.colorado.edu for password.

Bertram, T., et al. (2007), Direct measurements of the convective recycling of the upper troposphere, Science, 315, 816-820, doi:10.1126/science.1134548.

Bloom, S., et al. (2005), Documentation and validation of the Goddard Earth Observing System (GEOS) data assimilation system - Version 4. Technical Report Series on Global Modeling and Data Assimilation 104606.

Browell, E. V., et al. (1996), Ozone and aerosol distributions and air mass characteristics over the South Atlantic Basin during the burning season, J. Geophys. Res., 101, 24,04324,068.

Cooper, O. R., et al. (2006), Large upper tropospheric ozone enhancements above mid-latitude North America during summer: In situ evidence from the IONS and MOZAIC ozone networks, J. Geophys. Res., 111, D24So5, doi: 10.1029/2006JDoo7306.

Deshler, T., et al. (2008), Balloon experiment to test ECC-ozonesondes from different manufacturers, and with different cathode solution strengths: Results of the BESOS flight, J. Geophys. Res., 113,D04307, doi:10.1029/2007JDoo8975.

Dougherty, K. M. (2008), The effect of ozonopause placement on tropospheric ozone budgets: An analysis of ozonesonde profiles from selected IONS-06 sites, MS Thesis, The Pennsylvania State University.

Draxler, R. R., and G. D. Rolph (2003), HYSPLIT (Hybrid Single-Particle Lagrangian Integrated Trajectory) model, http://www.arl.noaa.gov/ready/hysplit4.html, NOAA Air Resour. Lab., Silver Spring, MD.

Edwards, D. P., et al. (2003), Tropospheric ozone over the tropical Atlantic: A satellite perspective, J. Geophys. Res., 108, 4237, doi: 10.1029/2002JDoo2927.

Fast, J. D., et al. (2007), A meteorological overview of the MILAGRO field campaign, Atmos. Chem. Phys. 7, 2233-2257.

Folkins, I., S. J. Oltmans, and A. M. Thompson (2000), Tropical convective outflow and nearsurface equivalent potential temperatures, Geophys. Res. Lett., 27, 2549-2552. 
Folkins, I., P. Bernath, C. Boone, K. Walker, A. M. Thompson, and J. C. Witte (2006), The seasonal cycles of $\mathrm{O}_{3}, \mathrm{CO}$ and convective outflow at the tropical tropopause, Geophys. Res. Lett., 33, L16802, doi:10.1029/2006GL026602.

Fortuin, P., et al. (2007), Origin and transport of tropical cirrus clouds observed over Paramaribo, Suriname $\left(5.8^{\circ} \mathrm{N}, 55.2^{\circ} \mathrm{W}\right), J$. Geophys. Res., 112, Do9107, doi:10.1029/2005JDoo6420.

Fueglistaler, S., A. E. Dessler, T. J. Dunkerton, I. Folkins, Q. Fu, and P. W. Mote (2009), Tropical tropopause layer, Rev. Geophys., 47, RG1004, doi:10.1029/2008RGo00267.

Fujiwara, M., K. Kita, and T. Ogawa (1998), Stratosphere-troposphere exchange of ozone associated with the equatorial Kelvin wave as observed with ozonesondes and rawinsondes, J. Geophys. Res., 103, No. D15, 19,173-19,182.

Fujiwara, M., F. Hasebe, M. Shiotani, N. Nishi, H. Vömel, and S. J. Oltmans (2001), Water vapor control at the tropopause by equatorial Kelvin waves observed over the Galápagos, J. Geophys. Res., 28, 3143-3146.

Grant, W. B., R. B. Pierce, S. J. Oltmans, and E. V. Browell (1998), Seasonal evolution of total and gravity wave induced laminae in ozonesonde data in the tropics and subtropics, Geophys. Res. Lett. 25, 1863-1866.

Hasebe, F., M. Fujiwara, N. Nishi, M. Shiotani, H. Vömel, S. Oltmans, H. Takashima, S. Saraspriya, N. Komala, and Y. Inai (2007), In situ observations of dehydrated air parcels advected horizontally in the Tropical Tropopause Layer of the western Pacific, Atmos. Chem. Phys., 7, 803-813.

Hlavka, D., L. Tian, W. Hart, L. Li, M. McGill, and G. Heymsfield (2010), Vertical cloud climatology during $\mathrm{TC}_{4}$ derived from high-altitude aircraft merged lidar and radar, $J$. Geophys. Res., this issue.

Johnson, B. J., S. J. Oltmans, H. Vömel, T. Deshler, C. Kroger, and H. G. J. Smit (2002), ECC ozonesondes pump efficiency measurements and sensitivity tests of buffered and unbuffered sensor solutions, J. Geophys. Res., 107(D19), 4393, doi: 10.1029/2001JDooo557.

Jonquières, I., A. Marenco, A. Maalej, and F. Rohrer (1998), Study of ozone formation and transatlantic transport from biomass burning emissions over West Africa during the airborne Tropospheric Ozone Campaigns TROPOZ I and TROPOZ II, J. Geophys. Res., 103, 19,059-19,073.

Kley, D., P. J. Crutzen, H. G. J. Smit, H. Vömel, S. J. Oltmans, H. Grassl and V. Ramanathan (1996) Observations of near-zero ozone over the convective Pacific: Effects on air chemistry, Science, 274, 230-233.

Logan, J. A., I. Megretskaia, R. Nassar, L.T. Murray, L. Zhang, K.W. Bowman, H.M. Worden, and M. Luo (2008), Effects of the 2006 El Nino on tropospheric composition as revealed by data from the TES, Geophys. Res. Lett., 35, Lo3816, doi:10.1029/2007GLo31698.

Loucks, A. L. (2007), Evaluation of dynamical sources of ozone laminae in the tropical troposphere and tropical tropopause layer, M.S. Thesis, Penn State University.

McGill, M. J., L. Li, W. D. Hart, G. M. Heymsfield, D. L. Hlavka, P. E. Racette, L. Tian, M. A. Vaughan, and D. M. Winker (2004), Combined lidar-radar remote sensing: Initial results from CRYSTAL-FACE, J. Geophys. Res., 109, Do7203, doi:10.1029/2003JD004030.

Morris, G. A., et al. (2010), Observations of ozone production in a dissipating convective cell during TC4, J. Geophys. Res., doi: 10.1029/2009JD 014098, submitted. Manuscript available at TC4 website. Contact btoon@lasp.colorado.edu for password.

Newell, R. N., V. Thouret, J. Y. N. Cho, P. Stoller, A. Marenco, and H. G. Smit (1999), Ubiquity of quasi-horizontal layers in the troposphere, Nature, 398, 316-319.

Oltmans, S.J., et al. (2001), Ozone in the Pacific tropical troposphere from ozonesonde observations, J. Geophys. Res., 106, 32503-32526. 
Oltmans, S. J., et al. (2004), Tropospheric ozone over the North Pacific from ozonesonde observations, J. Geophys. Res., 109, D15S01, doi: 10.1029/2003JDo03466.

Peters, W., P. Fortuin, H. Kelder, C.R. Becker, J. Lelieveld, P.J. Crutzen, and A.M. Thompson (2004), Tropospheric ozone over a tropical Atlantic station in the Northern Hemisphere: Paramaribo, Surinam $\left(6^{\circ} \mathrm{N}, 55^{\circ} \mathrm{W}\right)$, Tellus, 56, 21-34.

Petropavloskikh, I., E. Ray, S. M. Davis, K. Rosenlof, G. Manney, R. Shetter, S. Hall, K. Ullmann, L. Pfister, J. Hair, M. Fenn, M. Avery, and A. M. Thompson, (2010) Low ozone bubbles observed in the tropical tropopause layer during the $\mathrm{TC}_{4}$ campaign in $2007, J$. Geophys. Res., doi: 10.1029/2009JD012804, in press. Manuscript available at TC4 website. Contact btoon@lasp.colorado.edu for password.

Pierce, R. B., and W.B. Grant (1998), Seasonal evolution of Rossby and gravity wave induced laminae in ozonesonde data obtained from Wallops Island, Virginia, Geophys. Res. Lett., 25, 1859-1862.

Piotrowicz, S. R., H. Bezdek, G. Harvey, and M. Springer-Young (1991), On the ozone minimum over the equatorial Pacific Ocean. J. Geophys. Res. 96, 18679-18687.

Randel, W. J., D. J. Seidel, and L. L. Pan (2007), Observational characteristics of double tropopauses, J. Geophys. Res., 112, Do7309, doi:10.1029/2006JD007904.

Randriambelo, T., J-L. Baray, S. Baldy, A. M. Thompson, S. J. Oltmans, and P. Keckhut (2003), Investigation of the short-term variability of tropical tropospheric ozone, Annales Geophysiques, 21, 2095-2106.

Read, K. A. et al. (2008), Extensive halogen-mediated ozone destruction over the tropical Atlantic Ocean, Nature, 453, 1232-1235, doi: 10.1038/natureo7035.

Schoeberl, M. R., and L.C. Sparling (1995), Trajectory modeling: Diagnostic tools in atmospheric physics, S. I. F. Course CXVI, edited by G. Fiocco and C. Visconti, NorthHolland, Amsterdam.

Schoeberl, M. R., et al. (2006), Overview of the EOS aura mission, IEEE Trans., 44 (5), 10661074, doi:10.1109/TGRS.2005.861950.

Selkirk, H. B., H. Vömel, J. M. Valverde Canossa, L. Pfister, J. A. Diaz, W. Fernández, J. Amador, W. Stolz, and G. Peng, The detailed structure of the tropical upper troposphere and lower stratosphere as revealed by balloonsonde observations of water vapor, ozone, temperature and winds during the NASA TCSP and TC4 Campaigns, J. Geophys. Res., in press. ${ }^{* *}$ Manuscript available at TC4 website. Contact btoon@lasp.colorado.edu for password.

Smit, H. G. J., et al. (2007), Assessment of the performance of ECC-ozonesondes under quasiflight conditions in the environmental simulation chamber: Insights from the Jülich Ozone Sonde Intercomparison Experiment (JOSIE), J. Geophys. Res., 112, D19306, doi: 10.1029/2006JD007308.

Takashima, H., and M. Shiotani (2007), Ozone variation in the tropical tropopause layer as seen from ozonesonde data, J. Geophys. Res., 112, D11123, doi:10.1029/2006JDoo8322.

Teitelbaum, H., J. Ovarlez, H. Kelder, and F. Lott (1994), Some observations of gravity-waveinduced structure in ozone and water vapour during EASOE, Geophys. Res. Lett., 21, 1483-1486.

Teitelbaum, H., et al. (1996), The role of atmospheric waves in the laminated structure of ozone profiles at high latitude. Tellus, 48A, 442-455.

Thompson, A. M., et al. (1993), SAGA-3 ozone observations and a photochemical model analysis of the marine boundary layer during SAGA-3, J. Geophys. Res., 98, 1695516968.

Thompson, A. M., et al. (1996), Where did tropospheric ozone over southern Africa and the tropical Atlantic come from in October 1992? Insights from TOMS, GTE/TRACE-A and SAFARI-92, J. Geophys. Res., 101, 24,251-24,278.

Thompson, A. M., W.-K. Tao, K. E. Pickering, J. R. Scala, and J. Simpson (1997), Tropical deep convection and ozone formation, Bull. Amer. Met. Soc., 78, 1,043-1,054. 
Thompson, A. M., B. G. Doddridge, J. C. Witte, R. D. Hudson, W. T. Luke, J. E. Johnson, B. J. Johnson, S. J. Oltmans, and R. Weller (2000), A tropical Atlantic paradox: Shipboard and satellite views of a tropospheric ozone maximum and wave-one in JanuaryFebruary 1999, Geophys. Res. Lett., 27,3317-3320.

Thompson, A. M., et al. (2003a), Southern Hemisphere Additional Ozonesondes (SHADOZ) 1998-2000 tropical ozone climatology. 1. Comparison with TOMS and ground-based measurements, J. Geophys. Res., 108, 8238, doi: 10.1029/2001JDooo967.

Thompson, A. M., et al. (2003b), Southern Hemisphere Additional Ozonesondes (SHADOZ) 1998-200o tropical ozone climatology. 2. Tropospheric variability and the zonal waveone, J. Geophys. Res., 108, 8241, doi: 10.1029/2002JDo02241.

Thompson, A. M., et al. (2007a), IONS (INTEX Ozonesonde Network Study, 2004). 1. Summertime UT/LS (Upper Troposphere/Lower Stratosphere) ozone over northeastern North America, J. Geophys. Res., 112, D12S12, doi: 10.1029/2006JDo07441.

Thompson, A. M., J. C. Witte, H. G. J. Smit, S. J. Oltmans, B. J. Johnson, V. W. J. H. Kirchhoff, and F. J. Schmidlin (2007b), Southern Hemisphere Additional Ozonesondes (SHADOZ) 1998-2004 tropical ozone climatology. 3. Instrumentation, station variability, evaluation with simulated flight profiles, J. Geophys. Res., 112, D03304, doi: 10.1029/ 2005JDo07042.

Thompson, A. M., J. E. Yorks, S. K. Miller, J. C. Witte, K. M. Dougherty, G. A. Morris, D. Baumgardner, L. Ladino, and B. Rappenglueck (2008), Tropospheric ozone sources and wave activity over Mexico City and Houston during Milagro/Intercontinental Transport Experiment (INTEX-B) Ozonesonde Network Study, 2006 (IONS-o6), Atmos. Chem. Phys., 8, 5113-5125.

Thompson, A. M., A. L. Loucks, S. Lee, S. K. Miller (2010a), Gravity and Rossby wave influences in the tropical troposphere and lower stratosphere based on SHADOZ (Southern Hemisphere Additional Ozonesondes) soundings, 1998-2007, J. Geophys. Res., doi: 10.1029/2009JD013429, submitted.

Thompson, A. M., S. J. Oltmans, D. W. Tarasick, P. Von der Gathen, H. G. J. Smit, J. C. Witte (2010b), Strategic ozone sounding networks: Review of design and accomplishments, Atmos. Environ., in press.

Toon, O. B., et al. (2010), Planning and implementation of the Tropical Composition, Cloud and Climate Coupling Experiment (TC4), J. Geophys. Res., this issue. Manuscript available at TC4 website. Contact btoon@lasp.colorado.edu for password.

Torres, A. L., and A. M. Thompson (1993), Nitric oxide in the equatorial Pacific boundary layer: SAGA-3 measurements, J. Geophys. Res., 98, 16949-16954.

Yorks, J. E., A. M. Thompson, E. Joseph, and S. K. Miller (2009), The variability of free tropospheric ozone over Beltsville, Maryland $(39 \mathrm{~N}, 77 \mathrm{~W})$ in the summers 2004-2007, Atmos. Environ., 43, 1827-1838.

Zafiriou, O. C., M. McFarland, and R. H. Bromund (1980) Nitric oxide in seawater, Science, 207, 637-639, 1980.

FIGURE CAPTIONS -

Application of laminar identification (LID) method to typical sounding from Panamá.

Illustrated are normalized $\mathrm{O}_{3}$ (solid line), potential temperature (dotted line) and correlation between the two quantities (dashed). Correlation criteria for Rossby waves (RW) are within vertical lines between -0.3 and +0.3 (light blue). The latter designation is used in discussion of profiles and budgets. Gravity wave (GW) criterion of Pierce and Grant (1998; see their Figure 1) and Thompson et al. (2007a; Figure 3) calls for normalized $\mathrm{O}_{3}$ and $\theta$ correlation to reach 0.7 (vertical line; light green for budgets). For 
computation of the GW Index, a more restrictive criterion is used, namely, the corresponding $\mathrm{O}_{3}$ layer amplitude must exceed 0.1 (10\%), as in the darker green. An RW Index, not used here, is based on counting only ozone within dark blue. Curtain plots of $\mathrm{O}_{3}$ mixing ratio to $18 \mathrm{~km}$ during $\mathrm{TC}_{4}$ over (a) Alajuela, Costa Rica (ACR); (b) Las Tablas, Panamá (LTP). White dots refer to the ozonopause as described in the text. Mean profiles of ozone, temperature, relative humidity ( $\mathrm{RH}$ ) from surface to $20 \mathrm{~km}$ for: (a) Alajuela, Costa Rica (ACR); eight $\mathrm{O}_{3}$ profiles with slight interference from volcanic $\mathrm{SO}_{2}$ have been smoothed at $3 \mathrm{~km}$. For comparison, mean DC-8 profiles from the FASTOZ ozone instrument (green dots) are displayed. The profiles include landing and takeoffs from San Jose airport near Alajuela. (b) Las Tablas, Panamá. In the latter case, seven questionable $\mathrm{RH}$ profile segments are omitted from mean.

(a) Frequency of GW occurrence over LTP, ACR during July-August $2007 \mathrm{TC}_{4}$ sampling;

(b) mean GW frequency over Paramaribo and San Cristóbal, based on all 1999-2007 profiles. For (b) J-J-A and full year means are virtually the same because J-J-A frequencies fall about halfway between the annual maximum and minimum frequencies. Paramaribo did not launch during TC4; (c) annual GW frequency at Paramaribo. The latter is typical of near-equatorial SHADOZ sites [Thompson et al., 2010a]. (a) Amounts of $\mathrm{O}_{3}$ (in DU) from top of the BL to $20 \mathrm{~km}$, affected by GW, RW determined by LID [Thompson et al., 2007a] based on $\mathrm{O}_{3}$ and P-T-U soundings from days with both Las Tablas (LTP) and Alajuela (ACR) launches during TC4. (b) Same as (a) except for free tropospheric $\mathrm{O}_{3}$ segment of all LTP soundings during $\mathrm{TC}_{4}$. The free troposphere is defined from the top of the BL to the ozonopause, as illustrated in Figure 2; (c) same as (b) for $\mathrm{O}_{3}$ over ACR. The vertical dashed line distinguishes phases of convective activity (greater before 23 July 2007 and after 2 August, diminished in between), as detected in the sondes. Fig 6 (a) Ozone, RH, temperature profiles at ACR and LTP for 13 July 2007. Vertical bars refer to RW (blue) and GW (green) as described in Figure 1. (b) Uv-DIAL image of ozone from DC-8 flight from California to Costa Rica. Ozone $<40 \mathrm{ppbv}$, purple, is near surface and also at cloud outflow level, $\sim 10 \mathrm{~km}$, south of the ITCZ; the latter is the cloudy region at 1945 UTC. Note a thin cloud-outflow ozone lamina at $13 \mathrm{~km}$.

Fig 7 (a) Ozone, RH, temperature profiles at ACR and LTP for 22 July 2007. (b) convective cells with outflow layers denoted by arrows on 22 July 2007 near LTP from ER-2 Cloud Physics Lidar and Cloud Radar System composite image [Hlavka et al., 2010].

Fig 8 Daily mean mixing ratios of (a) $\mathrm{O}_{3}$; (b) CO, from NATIVE in Las Tablas, Panamá (7.8N,80.oN). NATIVE CO readings are higher than the median DC- 8 profile data (Figure 2 in Avery et 
al., 2010), although NATIVE $\mathrm{NO} / \mathrm{NO}_{\mathrm{y}}$ and $\mathrm{SO}_{2}$ suggest that pollution is infrequent, Fig 9 Profiles from August 2007 TC4 sampling (a) 2 August 2007; (b) 3 August; (c) 5 August. Labels as in Figure 6a. For 5 August, the DC- $8 \mathrm{O}_{3}$ measurement from profiling near LTP displayed a high- $\mathrm{O}_{3}$, low-CO layer [Avery et al., 2010] at 8-10 km. Also on 5 August, the ozonesonde package, caught in dissipating convection, was buffeted in updrafts and downdrafts between 2 and $5 \mathrm{~km}$, presumably due to balloon icing [Morris et al., 2010]. Only the final ascent profile appears in (c), so a GW signal indicating convection does not appear below $7 \mathrm{~km}$. However, the RW segment may denote ozone from pollution. (a) Ozone, CO from DC-8 spiral on 3 August 2007 at 1505-1535 UTC, suggests extratropical influence at 6-8 km, with convection at $5 \mathrm{~km}$ and above $8 \mathrm{~km}$. (b) 3 Aug $2007 \mathrm{ER}$ 2 sampling produced composite CPL-CRS image with convective cells (outflow at horizontal arrows) at $7.5 \mathrm{~N}, 80.5 \mathrm{~W}$. Vertical arrows mark LTP sonde launch. (c) Same as (b) except for 5 August.

Fig 11 Averaged ozone amounts (in DU) in the free troposphere affected by GW, RW determined by the laminar method using all $\mathrm{O}_{3}$ and P-T-U sounding from J-J-A 1999-2007 for San Cristóbal, Galapagos (0.89S,90W) and Paramaribo, Suriname (5.8N,55E) and, since 2005, for two Costa Rican launch sites near San Jose (Heredia in 2005-2006; Alajuela, 20 km distant, in 2007). The 2007 data at Las Tablas, Panamá, are from TC4. $\mathrm{BL} \mathrm{O}_{3}$ amounts (not shown) are 2 DU at San Cristóbal, 3.5 DU at Paramaribo and the Costa Rican sites. Fig 12 Gravity wave Indices (GWI) based on $\mathrm{O}_{3}$ and P-T-U soundings from the Paramaribo and San Cristóbal SHADOZ sites. 


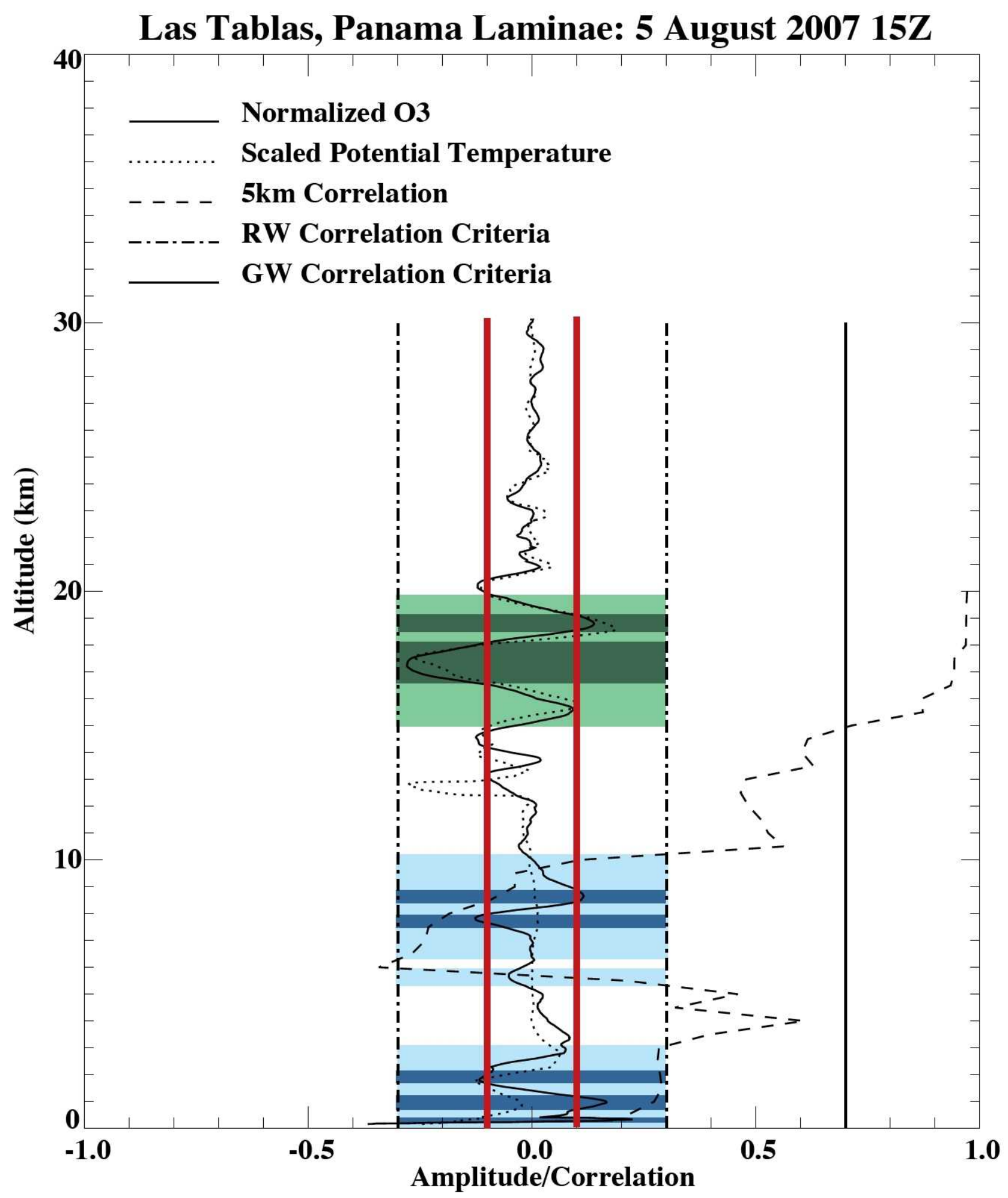

FIGURE 1 
$\mathbf{a}$ TC4 Ozonesondes: Alajuela, Costa Rica July-August 2007 Ozone Mixing Ratio (ppbv)
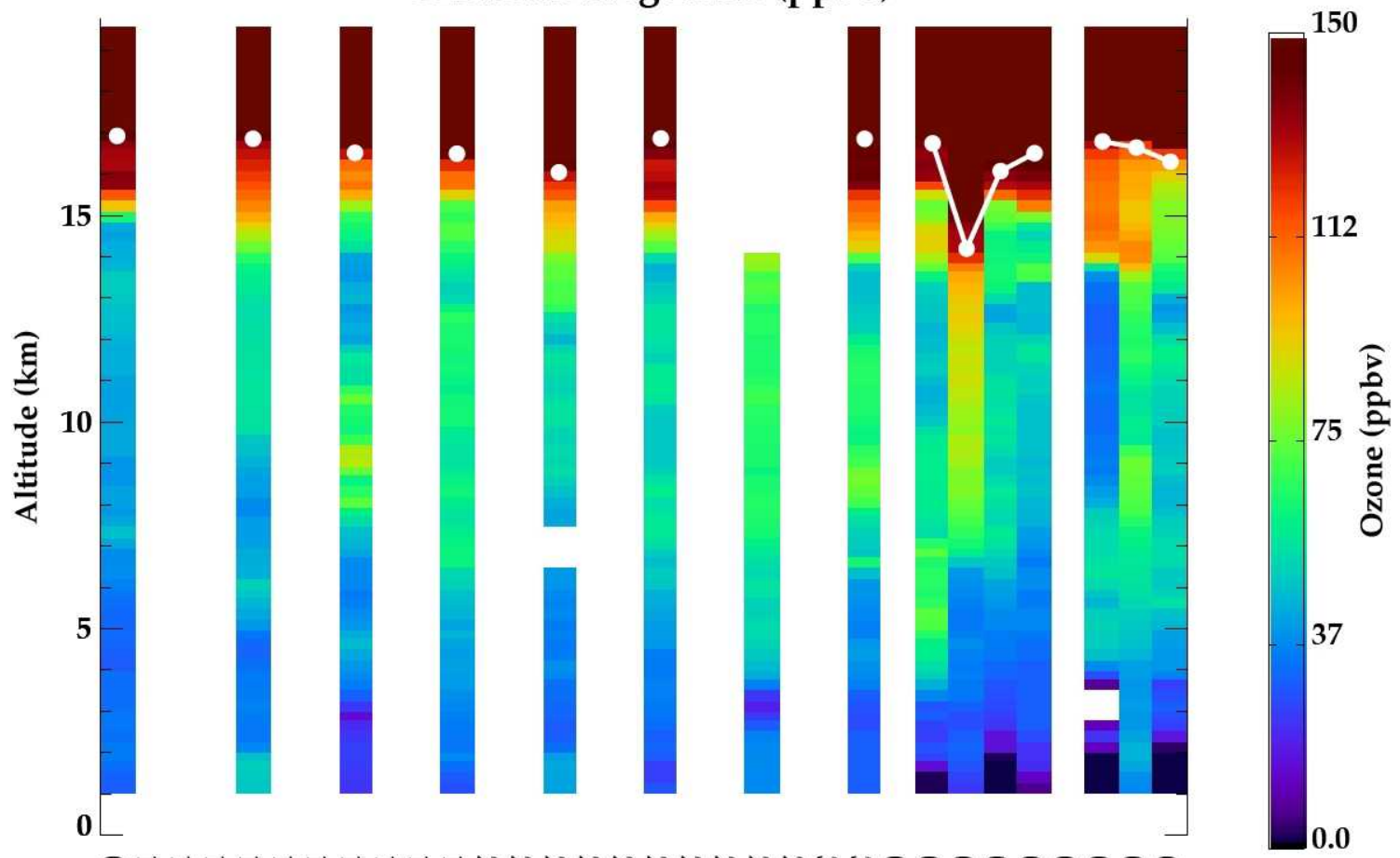

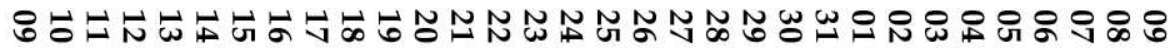
Day

b TC4 Ozonesondes: Las Tablas, Panama July-August 2007
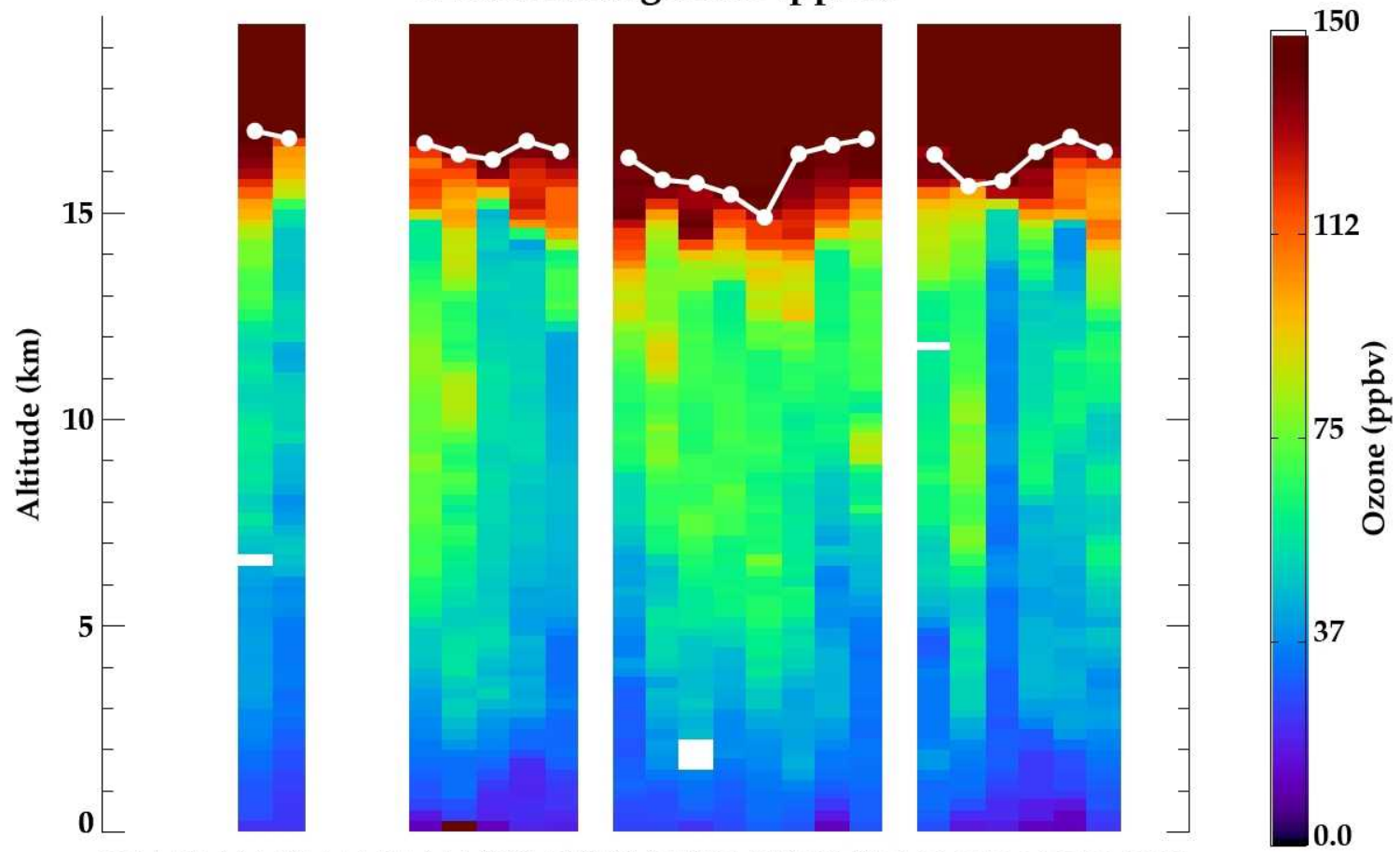

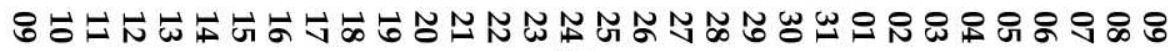

Day

FIGURE 2 

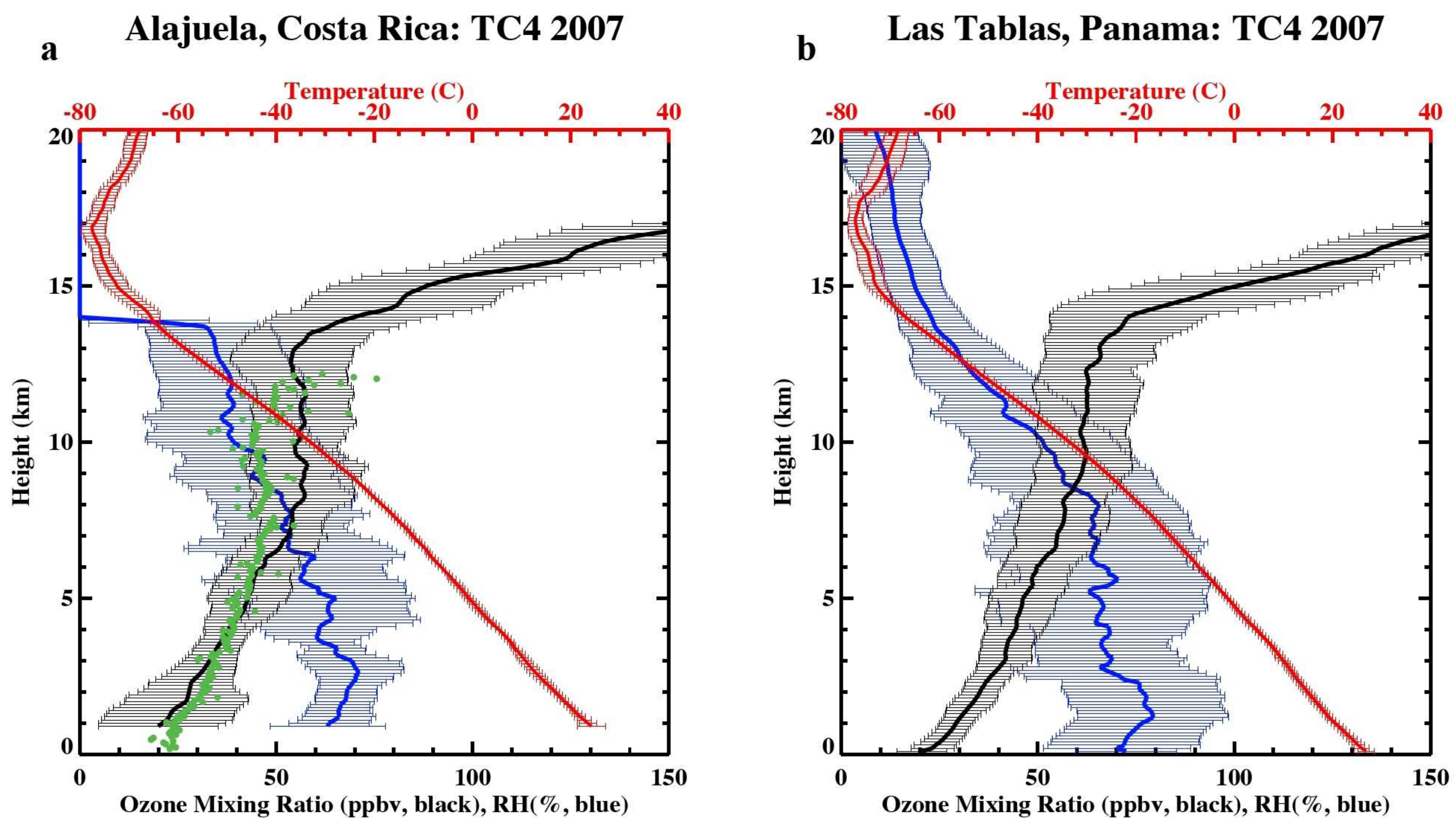

FIGURE 3 


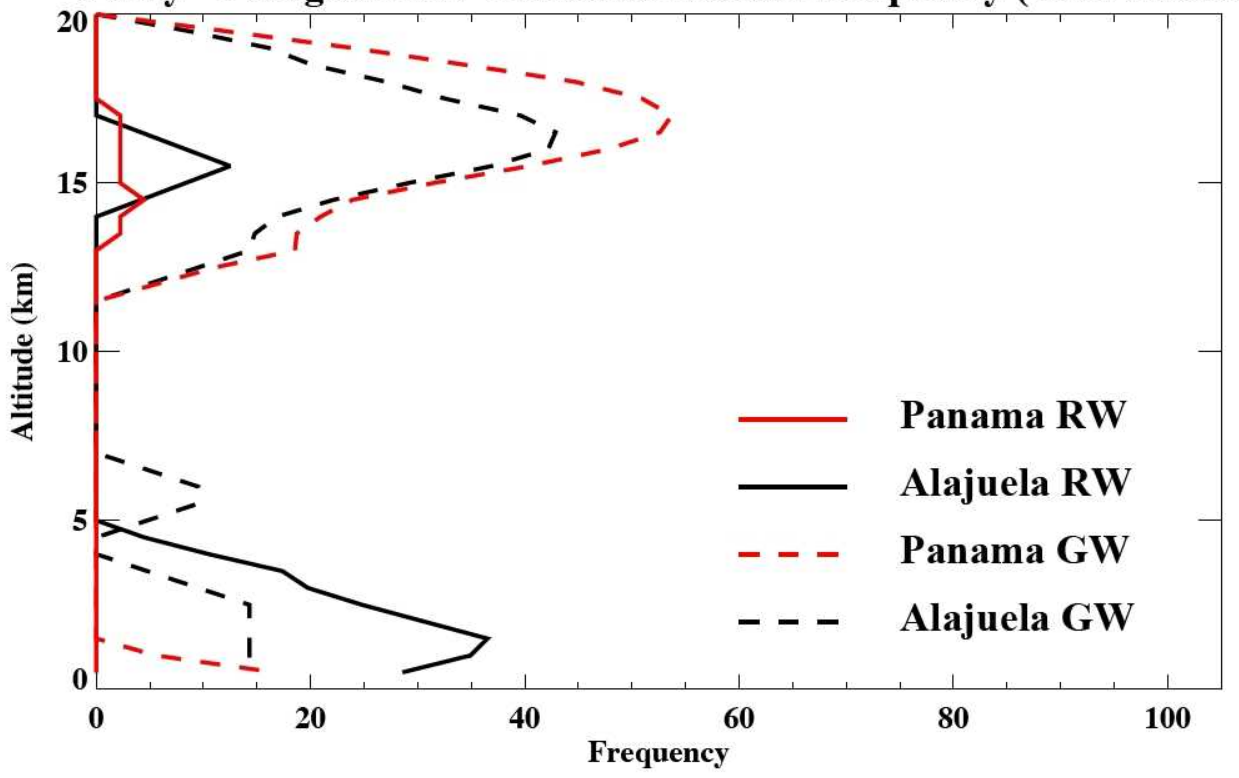

b

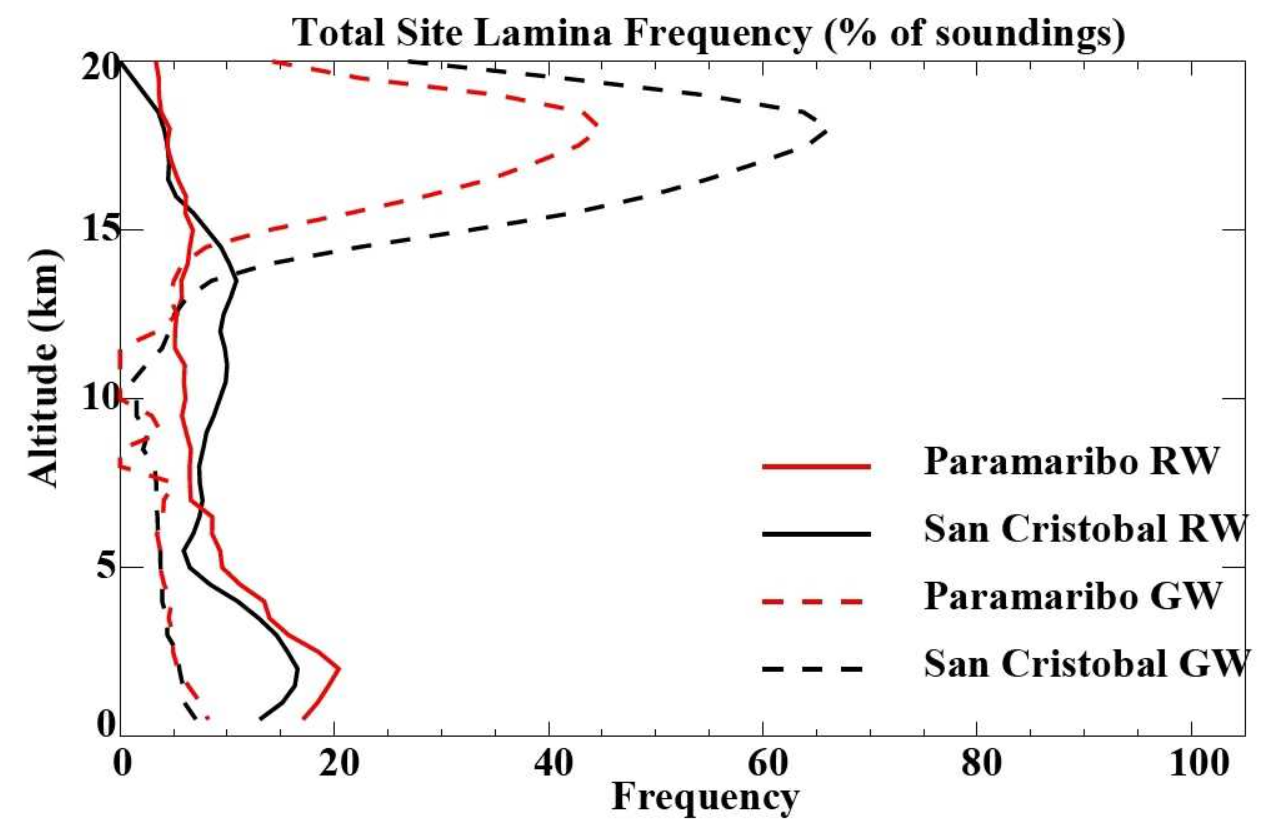

c

Paramaribo Lamina Frequency (\% of soundings) (Gravity Wave Lamina)

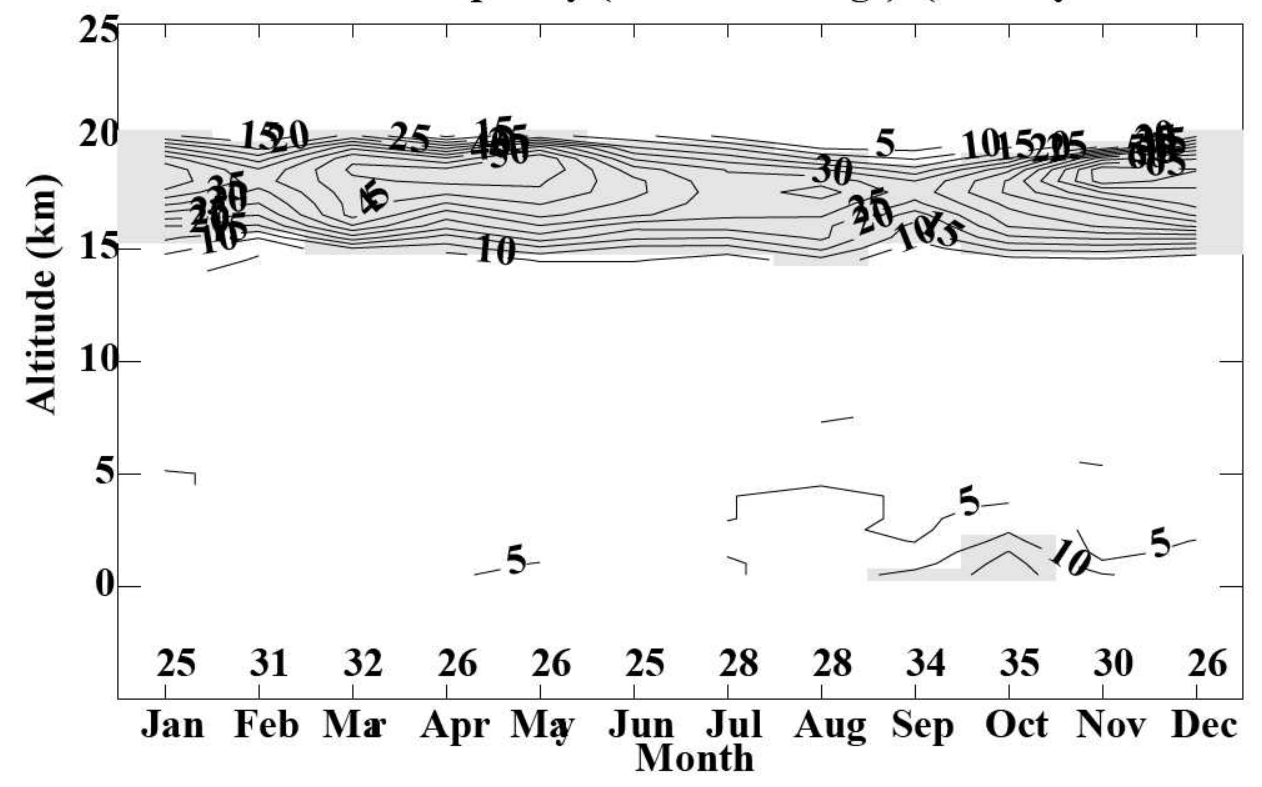

FIGURE 4 
a Ozone up to 20km: Las Tablas (LTP) and Alajuela (ACR) 2007

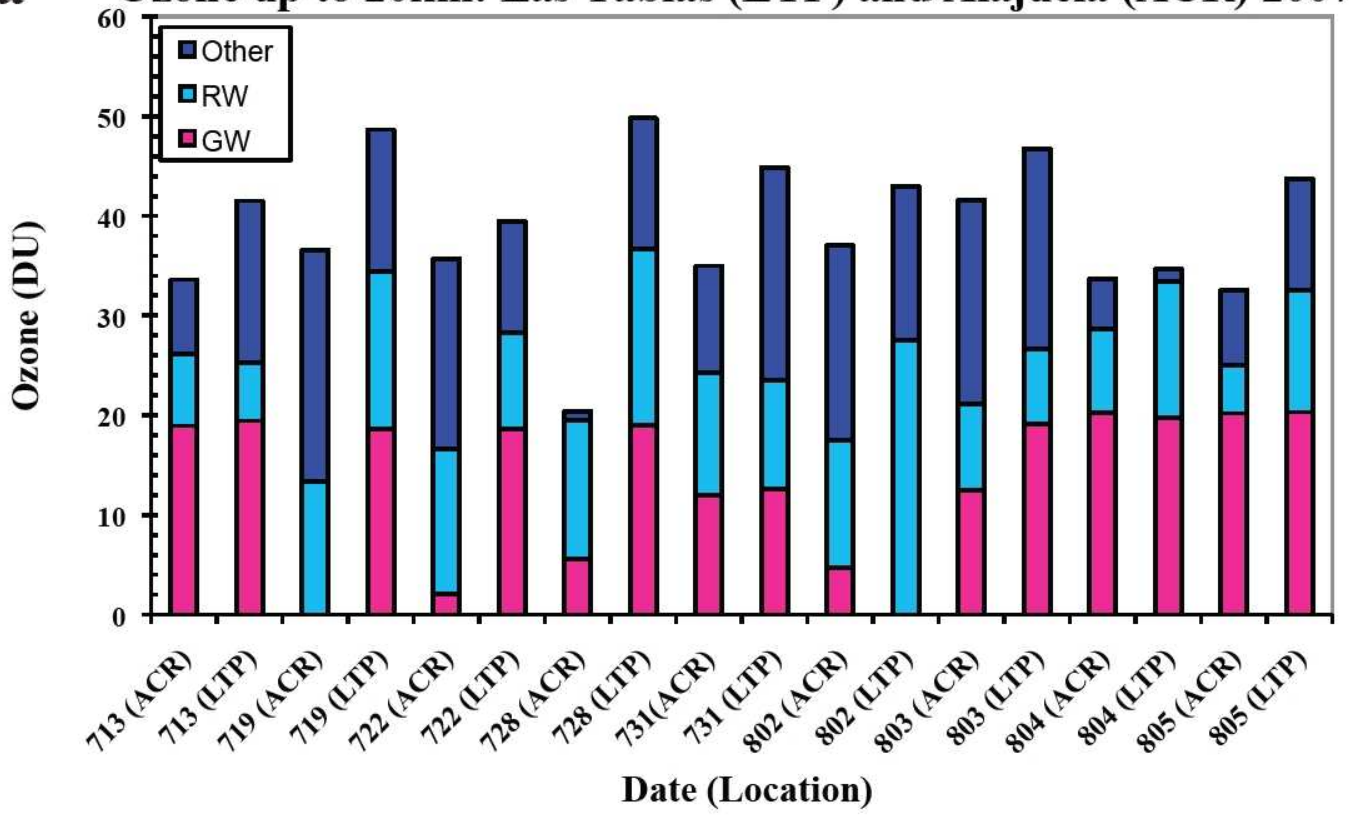

b Free Tropospheric $\mathrm{O}_{3}$ : Las Tablas, Panama 2007

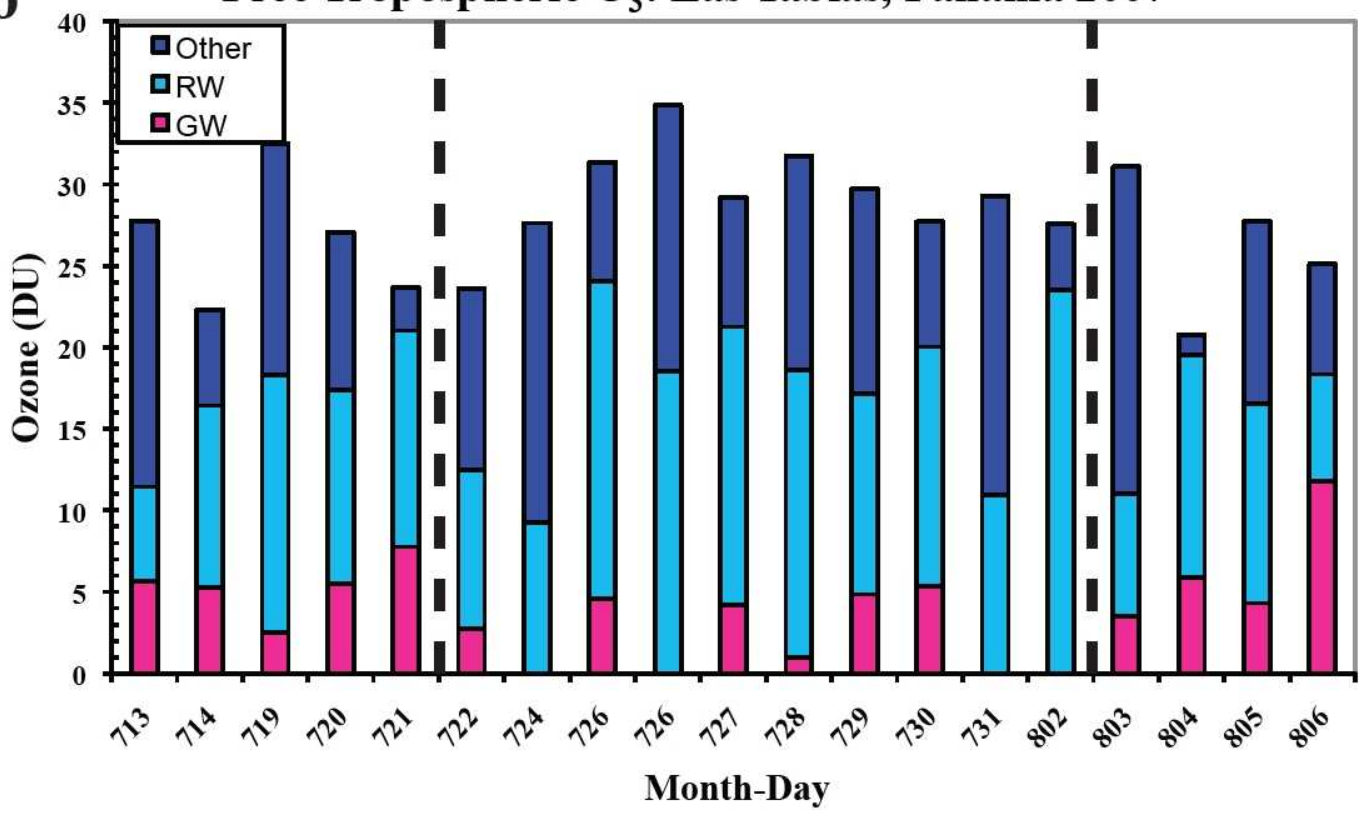

c

Free Tropospheric $\mathrm{O}_{3}$ : Alajuela, Costa Rica 2007

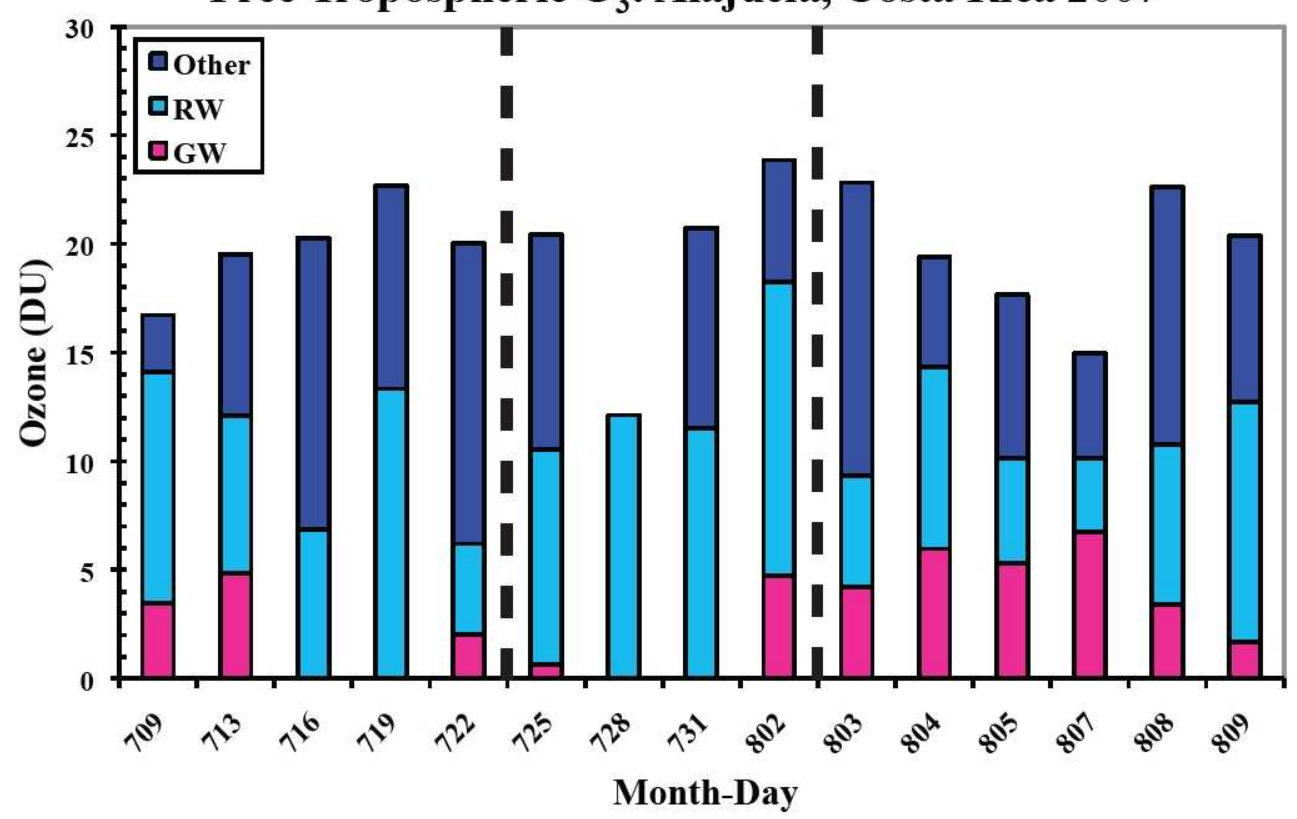

FIGURE 5 
$\mathbf{a}$

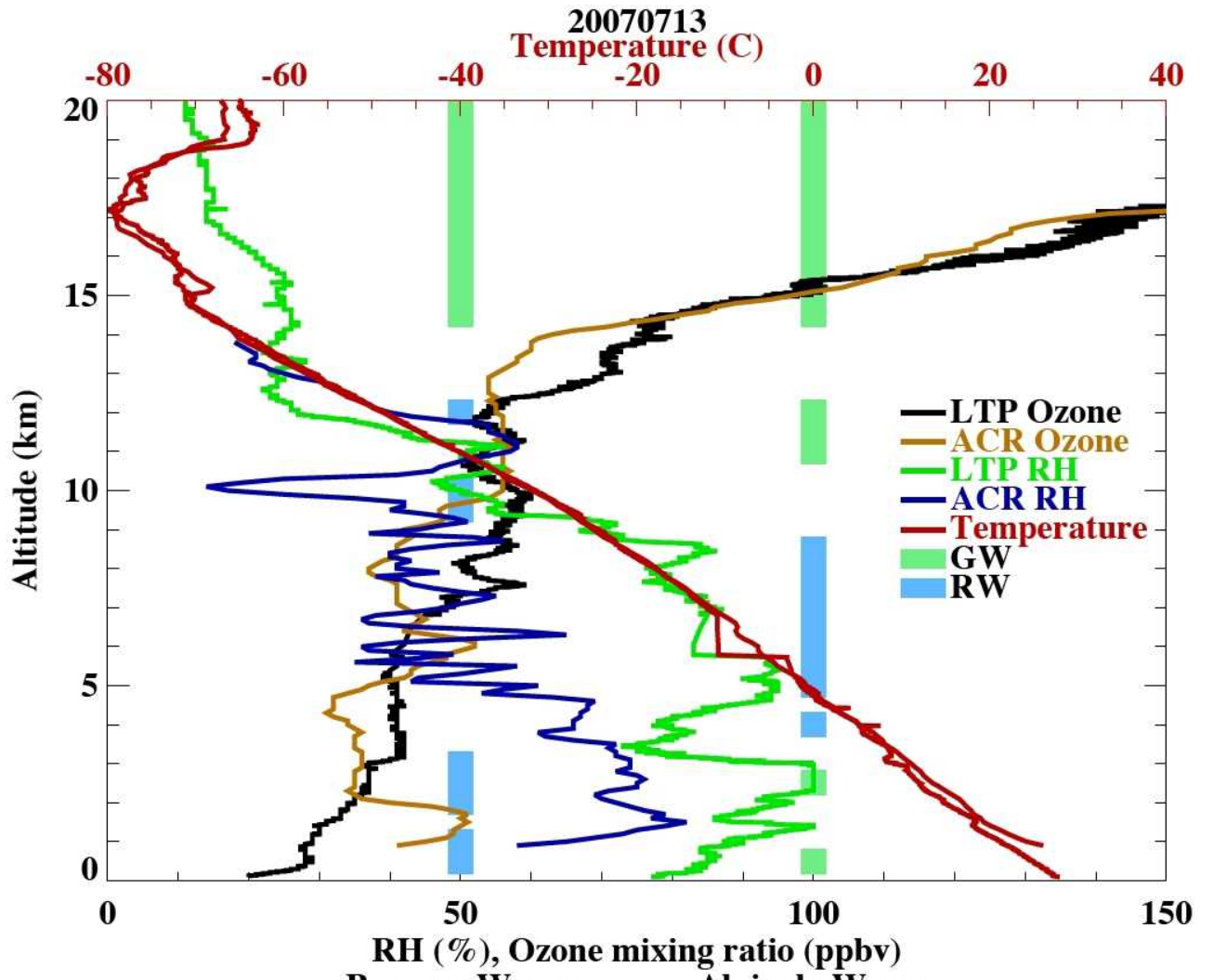

Panama Waves Alajuela Waves

b Ozone Mixing Ratio, ppbv \begin{tabular}{llllll}
0 & 25 & 50 & 75 & 100 & 125 \\
\hline
\end{tabular}
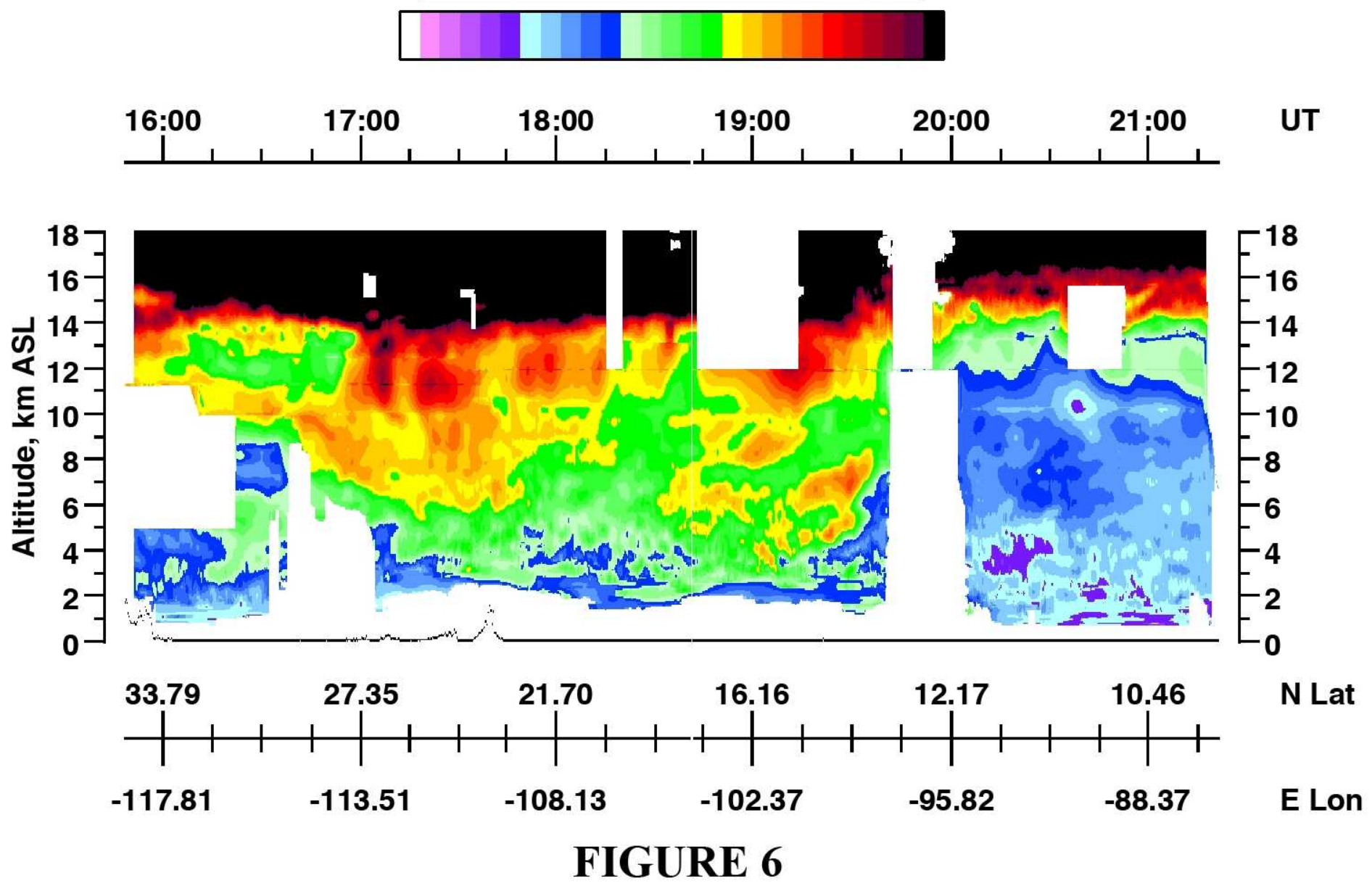


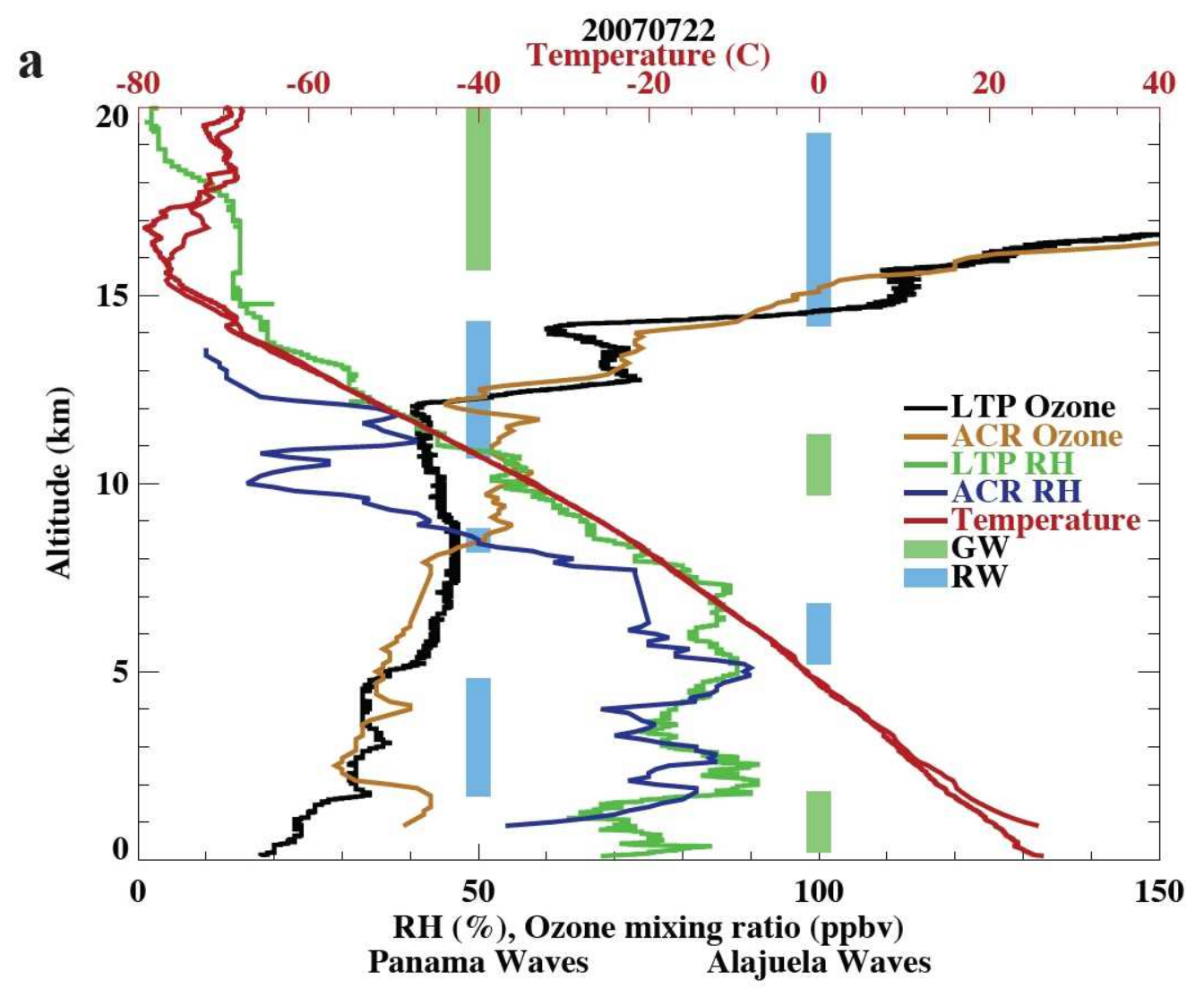

b

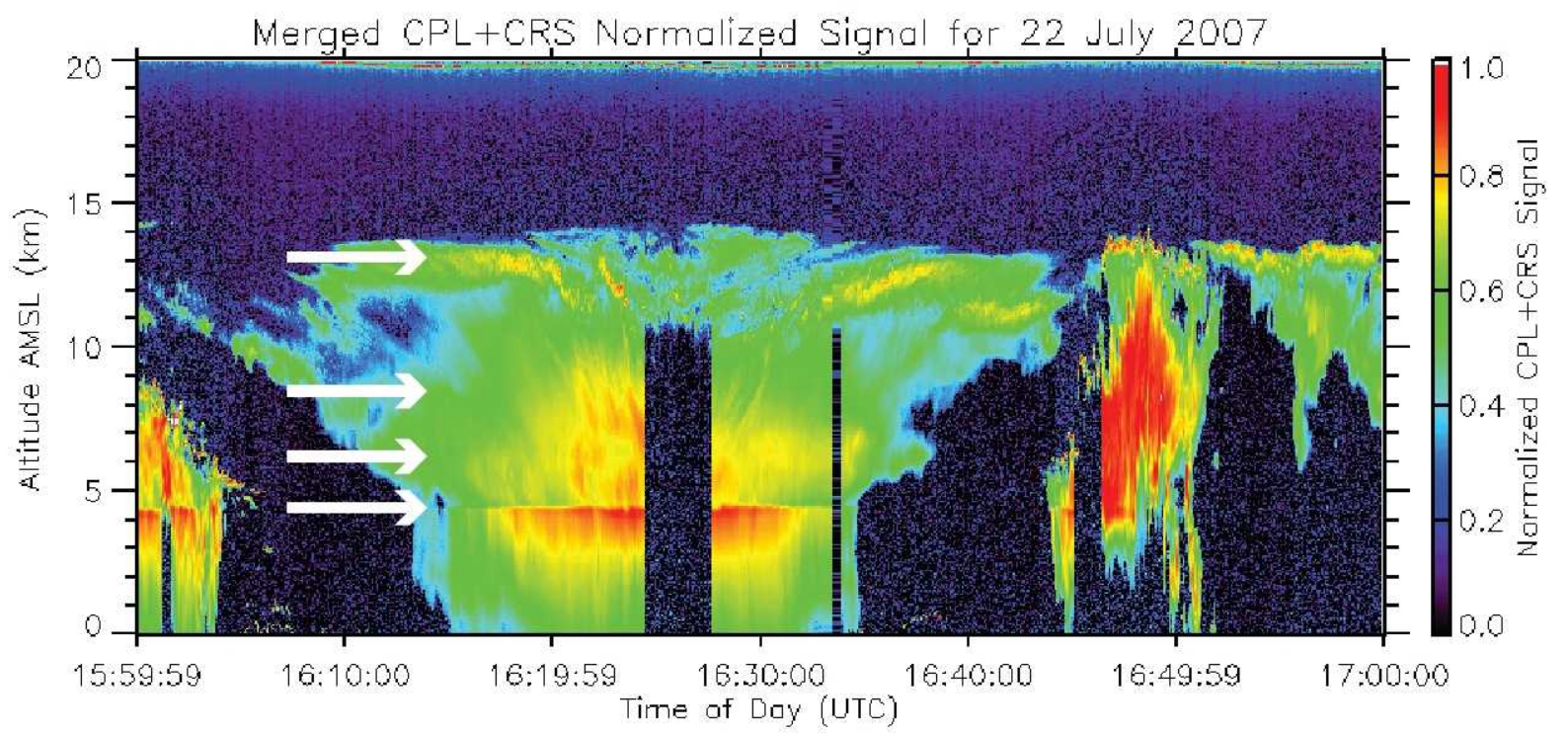

FIGURE 7 
Daily $\mathrm{O}_{3}$ Mean Concentrations, Las Tablas, TC4

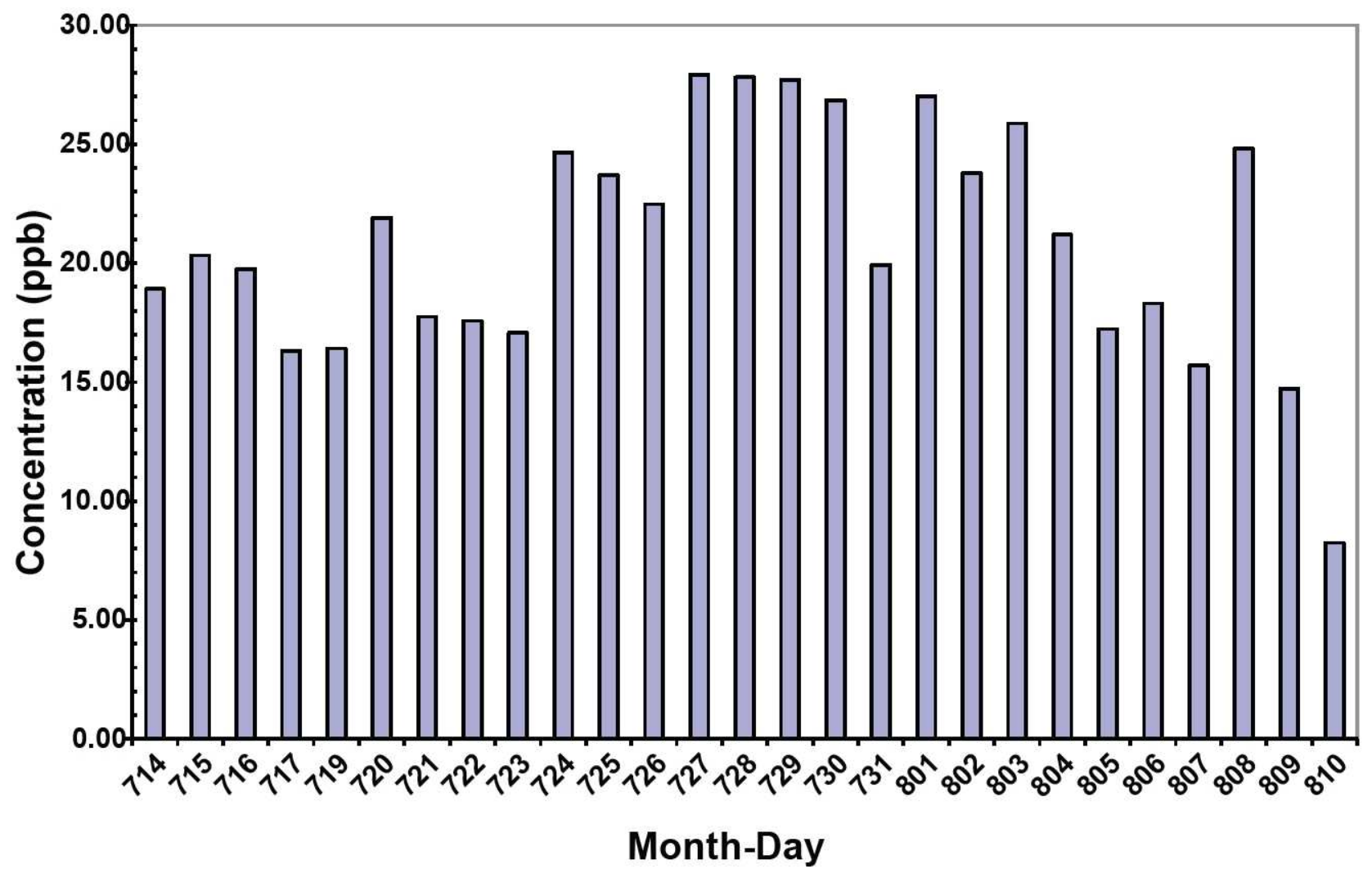

Daily CO Mean Concentrations, Las Tablas, TC4

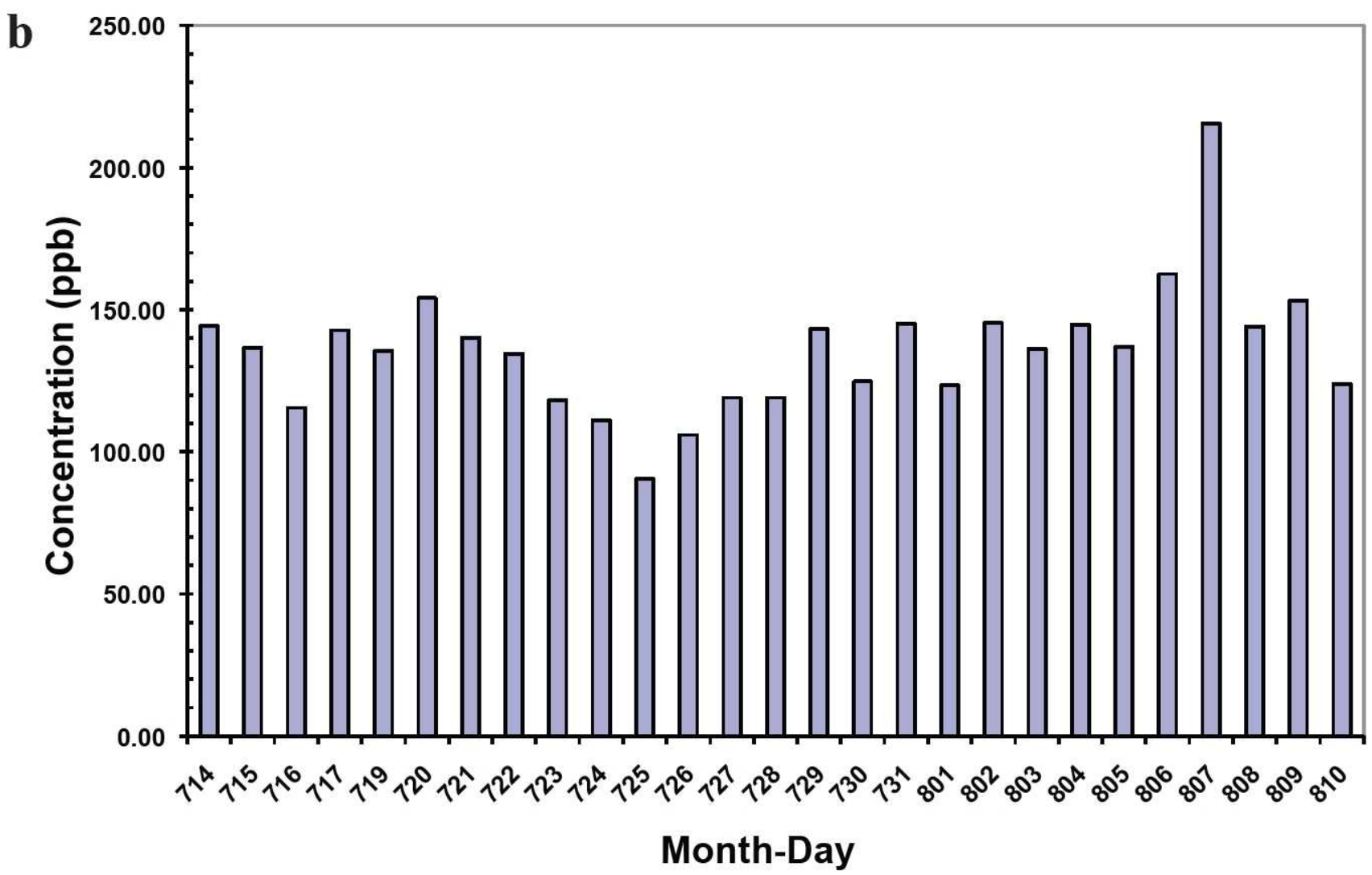

FIGURE 8 
a

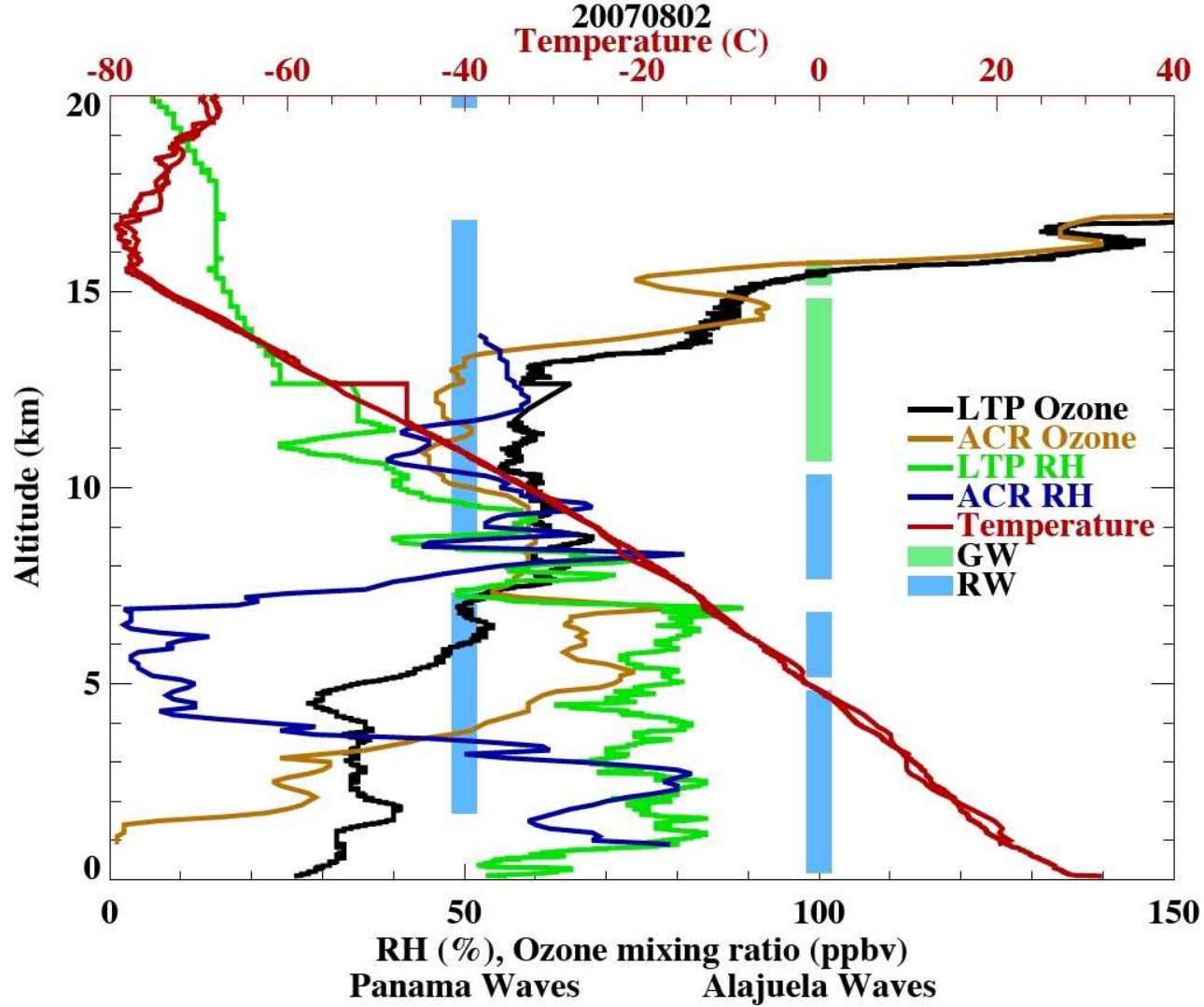

b

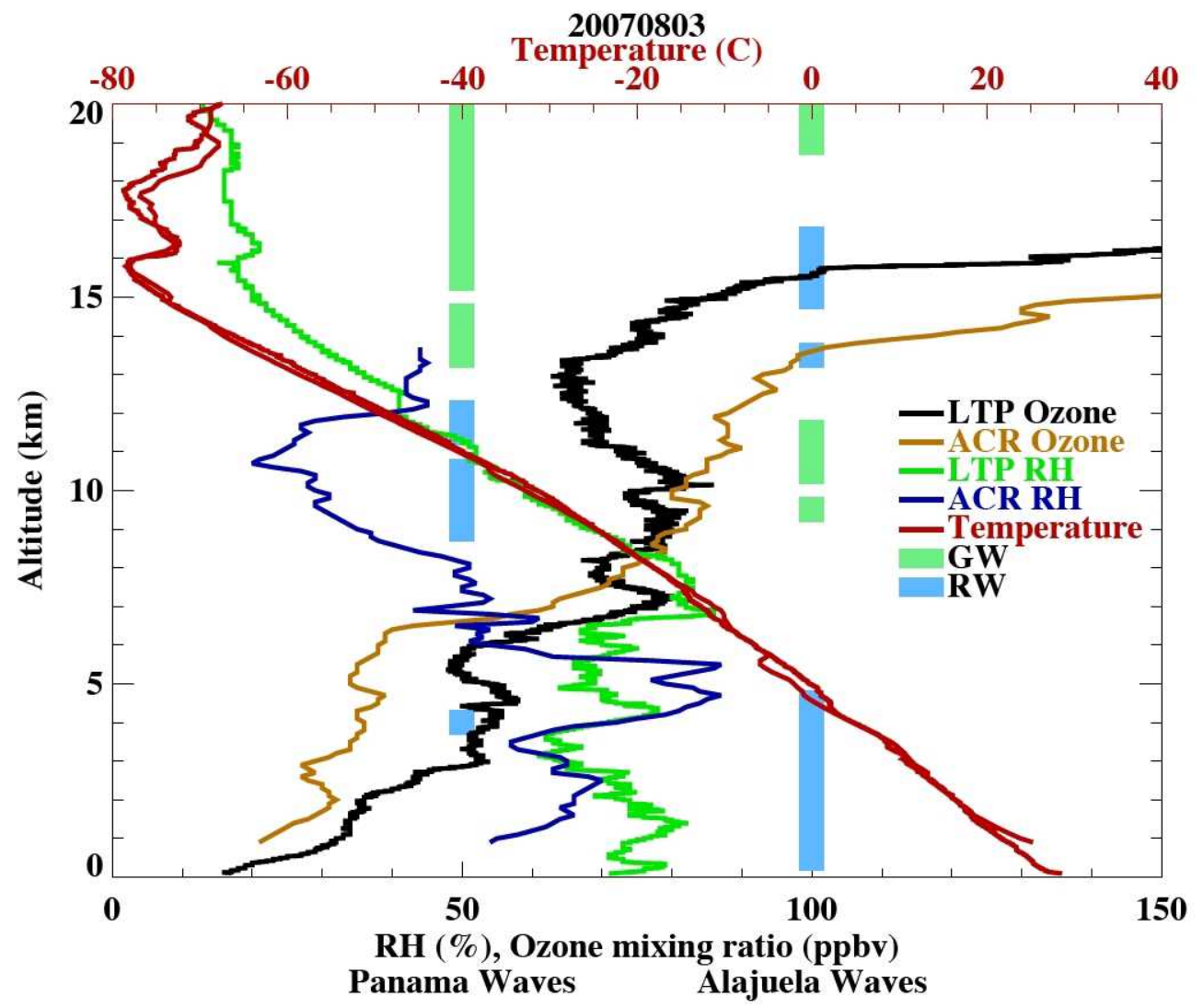

FIGURE 9 
c

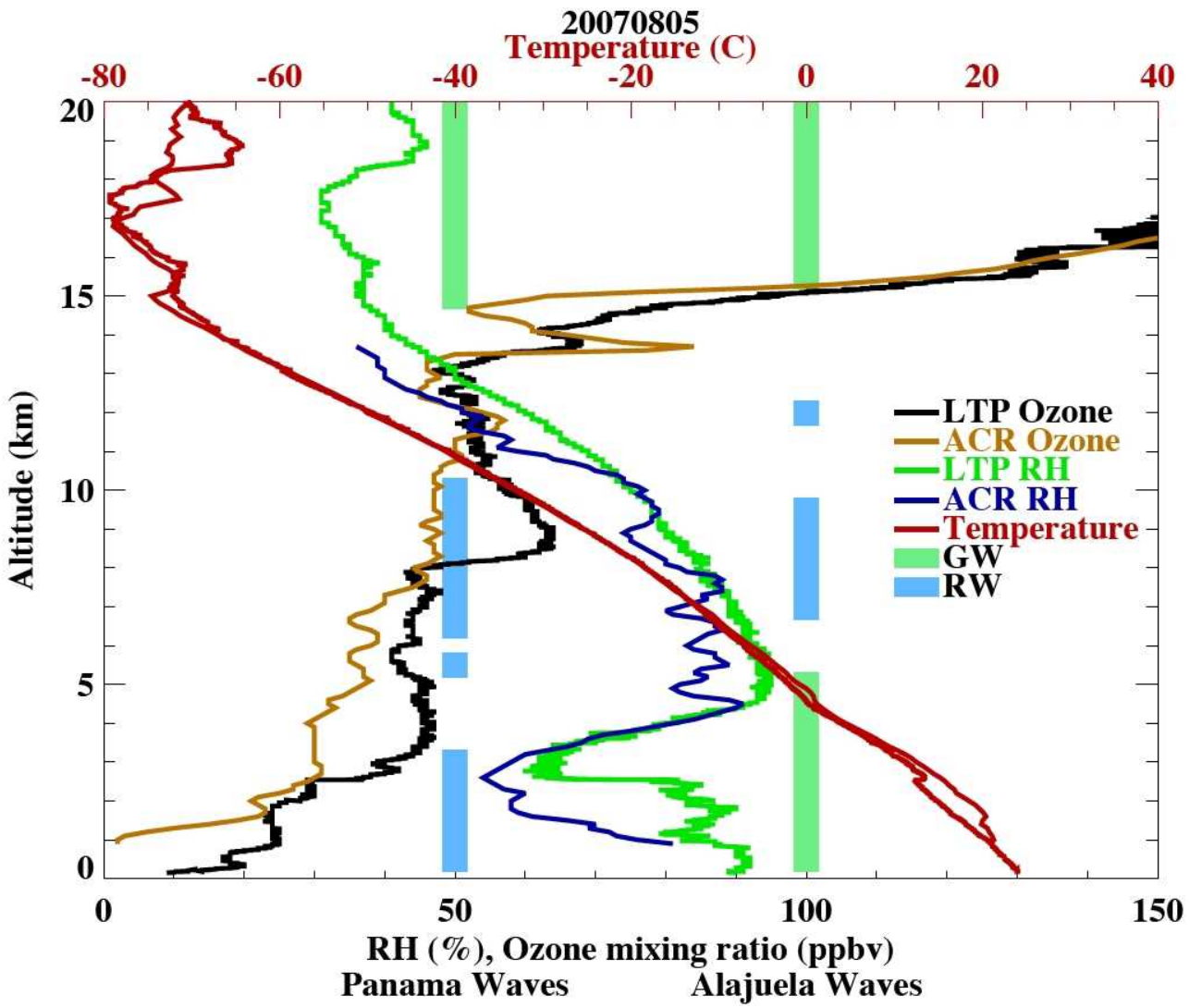

FIGURE 9 (continued) 

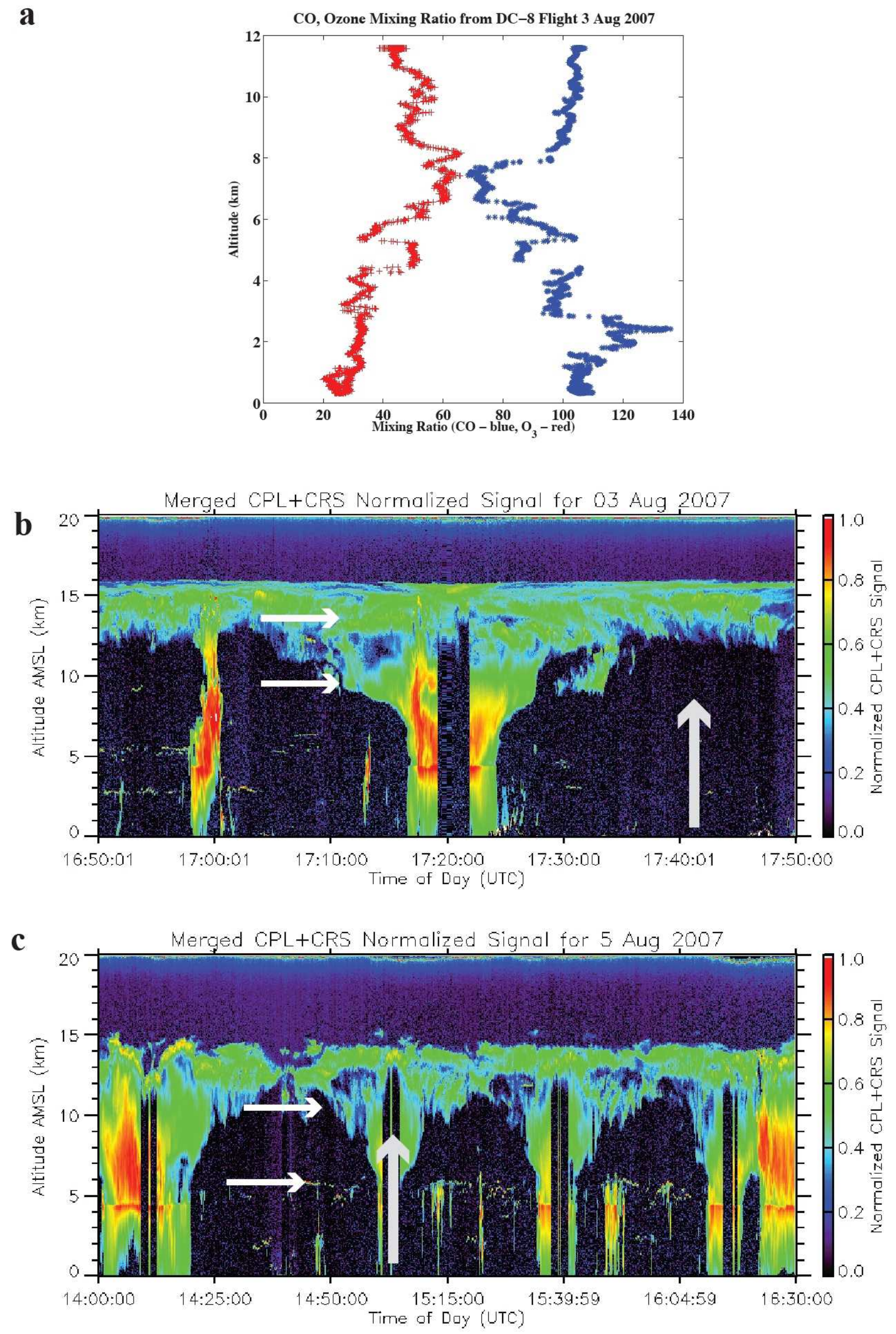


\section{Mean J-J-A Free Tropospheric Ozone}

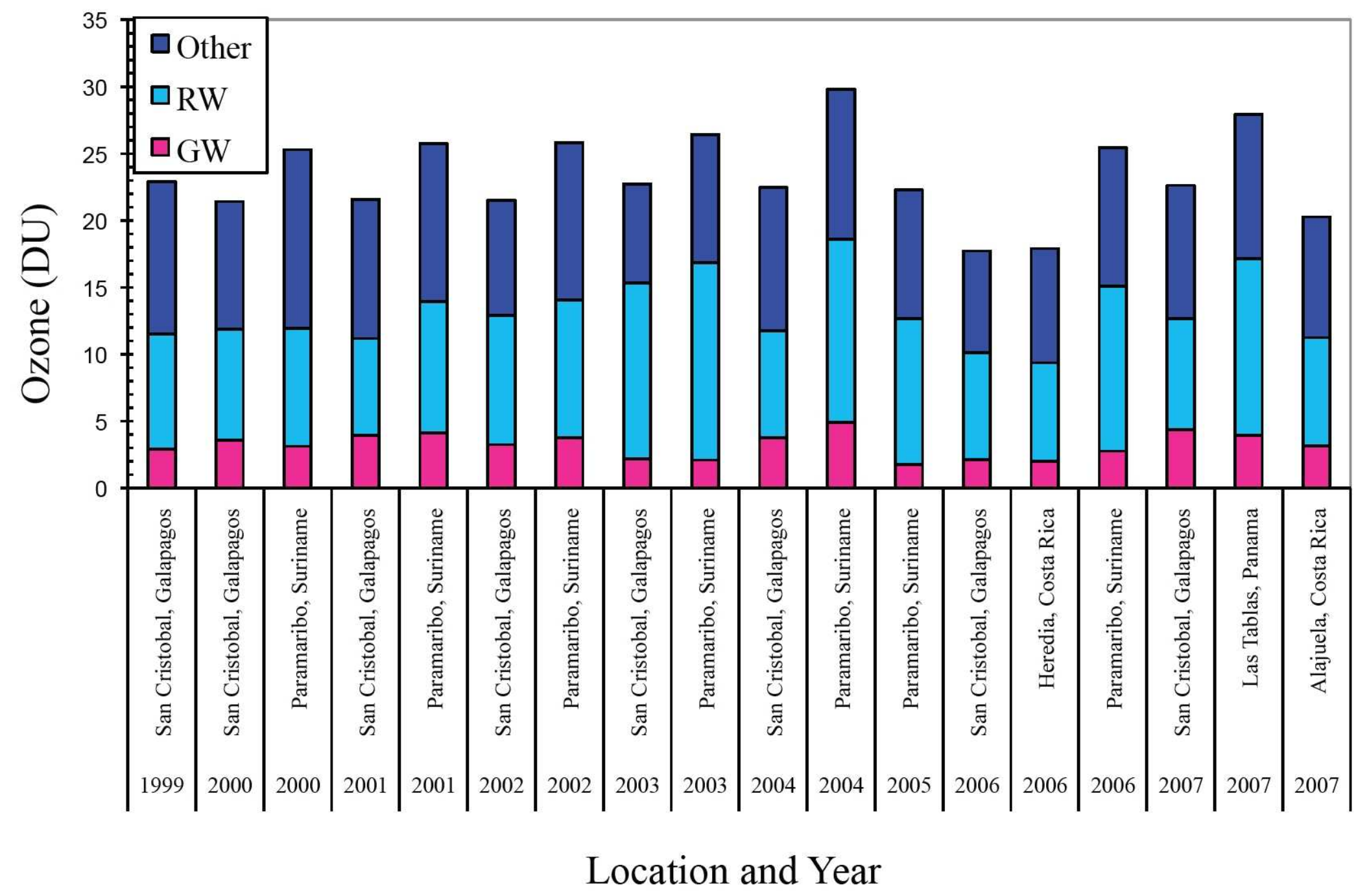

FIGURE 11 


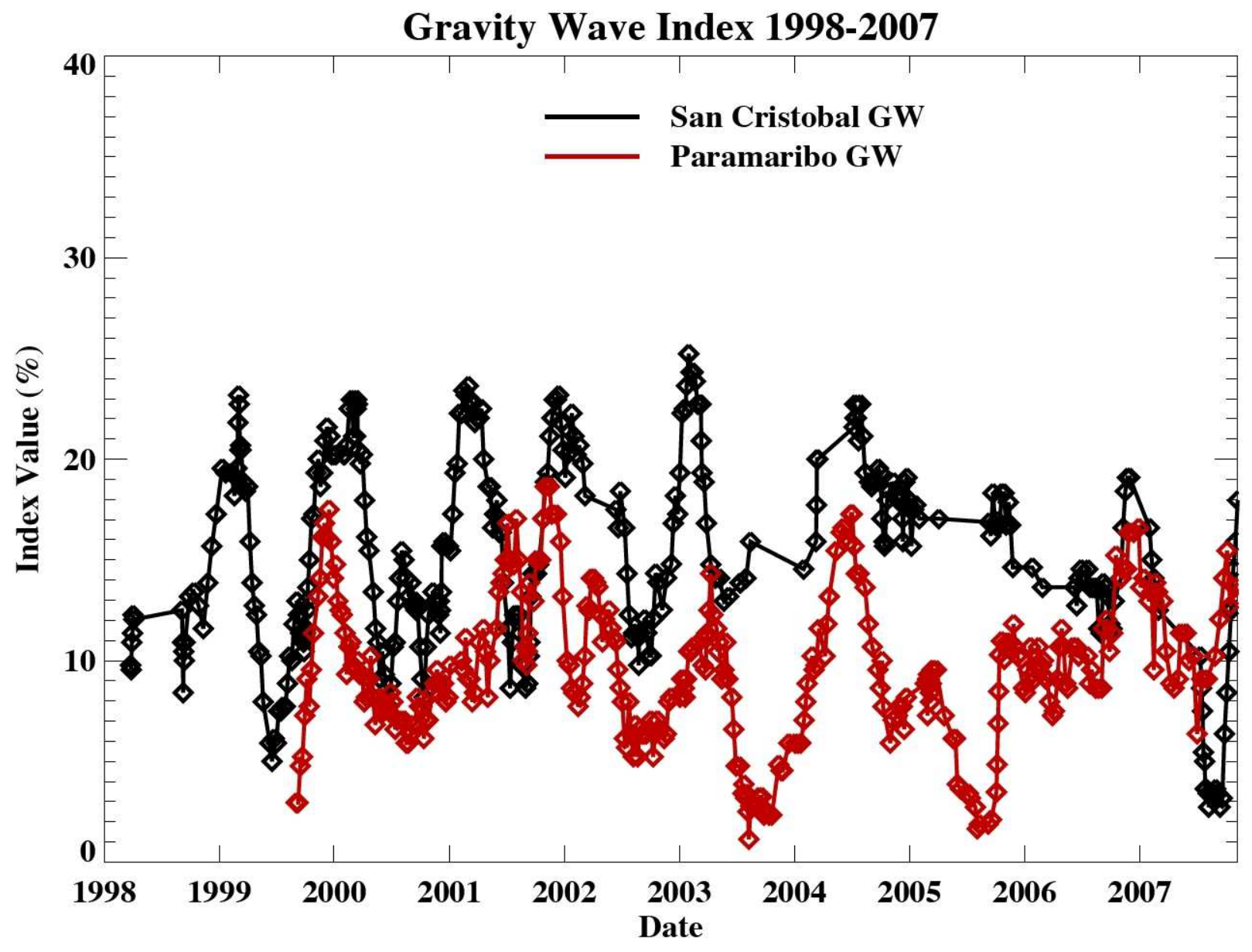

FIGURE 12 